NBER WORKING PAPER SERIES

\title{
PHARMACEUTICAL STOCK PRICE REACTIONS TO PRICE CONSTRAINT THREATS AND FIRM-LEVEL R\&D SPENDING
}

\author{
Joseph Golec \\ Shantaram Hegde \\ John Vernon \\ Working Paper 11229 \\ http://www.nber.org/papers/w11229
NATIONAL BUREAU OF ECONOMIC RESEARCH
1050 Massachusetts Avenue
Cambridge, MA 02138
March 2005

\begin{abstract}
We are very grateful to a the following individuals for their very helpful comments and suggestions on earlier versions of this paper: Ernest Berndt, Jean Paul Gagnon, Carmelo Giaccotto, Richard Manning, Sean Nicholson, Rexford Santerre, John M. Vernon, Y. Richard Wang and participants at the 2005 AEA/PEPC meetings in Philadelphia. We thank AstraZeneca and the Center for International Business \& Education Research at the University of Connecticut for financial support. All errors are our own. The views expressed herein are those of the author(s) and do not necessarily reflect the views of the National Bureau of Economic Research.
\end{abstract}

(O2005 by Joseph Golec, Shantaram Hegde, and John Vernon. All rights reserved. Short sections of text, not to exceed two paragraphs, may be quoted without explicit permission provided that full credit, including $\odot$ notice, is given to the source. 
Pharmaceutical Stock Price Reactions to Price Constriant Threats and Firm-Level R\&D Spending Joseph Golec, Shantaram Hegde, and John Vernon

NBER Working Paper No. 11229

March 2005, Revised November 2005

JEL No. G31, O32, L65, I1, K2

\begin{abstract}
Political pressure in the United States is again building to constrain pharmaceutical prices either directly or through legalized reimportation of lower-priced pharmaceuticals from foreign countries. This study uses the Clinton Administration's Health Security Act (HSA) of 1993 as a natural experiment to show how threats of price constraints affect firm-level R\&D spending. We link events surrounding the HSA to pharmaceutical company stock price changes and then examine the crosssectional relation between the stock price changes and subsequent unexpected R\&D spending changes. Results show that the HSA had significant negative effects on firm stock prices and R\&D spending. Conservatively, the HSA reduced R\&D spending by $\$ 1.6$ billion, even though it never became law. If the HSA had passed, and had many small firms not raised capital just prior to the HSA, the R\&D effects could have been much larger.

Joseph Golec

University of Connecticut

Department of Finance

2100 Hillside Road

Storrs, CT 06269

jgolec@business.uconn.edu

Shantaram Hegde

University of Connecticut

Department of Finance

2100 Hillside Road

Storrs, CT 06269

shegde@business.uconn.edu

John Vernon

University of Connecticut

Department of Finance

2100 Hillside Road

Storrs, CT 06269

and NBER

jvernon@business.uconn.edu
\end{abstract}


Can proposed government policy that significantly affects the stock prices of research and development (R\&D) intensive firms affect their R\&D spending decisions? The Clinton Administration's Health Security Act (HSA) provides a natural experiment to study this issue because it never passed Congress but nonetheless caused significant stock price declines for pharmaceutical firms. This study investigates the effects that price constraints proposed in the HSA had on pharmaceutical stock prices and subsequent firm-level R\&D spending.

The link from R\&D to stock prices has been studied by Chan, Lakonishok, and Sougiannis (2001) and Eberhart, Maxwell and Siddique (2004), but neither considers the link from stock prices to subsequent R\&D spending. Durnev, Morck, and Yeung (2004) find a link from stock price changes to investment spending, so there could be a similar link from stock prices to comparatively flexible R\&D spending. If investors expected the HSA to reduce the value of pharmaceutical $R \& D$, then firms' stock prices should fall, and managers could respond by reducing $R \& D$ spending, at least in the short-run.

Ellison and Mullin (2001) have linked the ferocious political debate on the HSA to the extremely poor stock returns for pharmaceutical firms during 1992-1993. They find that their sample of 18 large pharmaceutical company stocks suffered an average 38 percent loss during the period (-52 percent risk-adjusted). We find similar negative returns, but for a wider variety of 111 pharmaceutical and biotechnology companies. More important, we show that the higher the R\&D intensity, the larger the loss, with top quartile firms losing 60 percent on average (93 percent risk adjusted).

After illustrating how the HSA had significant effects on pharmaceutical stock prices, particularly those of R\&D intensive firms, we consider whether pharmaceutical firms responded by reducing their subsequent $R \& D$ spending. To study this issue, we need to link the HSA more closely to firms' stock price declines and then link those declines to their R\&D spending. We do not claim that the HSA caused all of the cumulative declines in pharmaceutical stock prices during 1992-1993. Nevertheless, industry executives claim that the HSA marked the start of 
constant political pressure to monitor and contain average drug prices, ${ }^{1}$ and since then, pharmaceutical price inflation has received much attention ${ }^{2}$. Therefore, although the total effect of the HSA alone may be uncertain, we show that a few surprise events closely associated with it had significant negative effects on pharmaceutical stock prices. Furthermore, we show that firms' abnormal returns surrounding the events are positively related to their subsequent R\&D spending changes.

The notion that product pricing or profitability is positively related to $R \& D$ spending seems straightforward. In one of the few precise studies of this issue, Finkelstein (2004) shows that exogenous government policies used to boost particular vaccines' profitability led to greater R\&D spending on those vaccines. Acemolgu and Linn (2005) suggest that pharmaceutical R\&D responds to the exogenous demographic changes driving revenues. But a positive relation between R\&D spending and profit is not a foregone conclusion. Ellison and Mullin (2001) suggest that the HSA caused a pure wealth transfer from pharmaceutical firms to consumers, and that stock price declines might not lead to reduced R\&D spending.

At the industry level, studies by Scherer (2001), Vernon (2005, 2003), and Giaccotto, Santerre, and Vernon (2005) show that policies designed to lower average pharmaceutical prices lead to lower R\&D spending. At the company level, Lichtenberg (2004) uses a sample of 46 pharmaceutical firms to identify a time series cross-sectional link between pharmaceutical stock price changes and R\&D spending during 1953-1996. He conjectures that the HSA could have caused the significant pharmaceutical stock price declines in 1993, and the subsequent industry-

\footnotetext{
${ }^{1}$ We thank Jean Paul Gagnon of Aventis, Y. Richard Wang of AstraZeneca, and Richard Manning of Pfizer for this insight. After the HSA, examples or indirect pressure on pharmaceutical prices includes discounts required on pharmaceuticals supplied to Medicaid and Veterans Administration and reimportation of pharmaceuticals from price regulated countries. Tessoriero (2004) suggests that political pressure can be observed in the year before presidential elections when pharmaceutical price increases tend to be subdued.

${ }^{2}$ A search of the Wall Street Journal confirms this. Average drug price inflation is discussed in only three articles from 1984 until 1992. During the HSA event period of 1992-1993, 12 such articles appeared, and from 1994 through 2005, 42 articles appeared. Therefore, the 1992-1993 HSA event period can be viewed generally as the time when the industry, and stock investors, realized that pharmaceutical pricing would be more politicized if not federally regulated.
} 
level R\&D spending growth declines in 1994 and 1995. But he does not measure firm-specific HSA-related returns, nor does he isolate the relation between those returns and firm-level R\&D spending during these years.

Our study focuses on this cross-sectional relation during 1993-1995. It attempts to account for the differential effects that an exogenous government policy (the HSA) could have on firms' R\&D portfolio values, and consequently, their stock prices. We expect the most vulnerable firms to have large R\&D portfolios as a proportion of firm value, but also those with more marginal R\&D projects. To measure firms' marginal R\&D projects, we employ the real options perspective. Marginal projects are equivalent to leveraged assets, hence, we measure $R \& D$ leverage using firms' betas. Results show that beta levels and HSA-induced changes help to explain changes in firms' stock prices and R\&D spending.

Ellison and Mullin (2001) claim that the HSA should not affect R\&D spending because most drug prices include large economic rents. The HSA simply reallocated rents. This is equivalent to assuming that drug $\mathrm{R} \& \mathrm{D}$ options are mostly low-risk and deep in-the-money. But our analysis shows that $\mathrm{R} \& \mathrm{D}$ intensive, high risk firms experience relatively large negative returns. Many of them are biotech firms. A sharp drop in external financing available to biotech firms after the HSA, documented by Lerner, Shane, and Tsai (2003), is consistent with the sharp declines in their stock prices. It is also consistent with our finding that risk effects are driven by firm liquidity. Firms that have accumulated significant liquidity are likely to be planning more projects, and could continue to spend on $\mathrm{R} \& \mathrm{D}$, even in the face of price regulation. Consequently, they are particularly vulnerable to the HSA and their stock prices could fall more.

Overall, we find that firms responded to declines in their stock prices by reducing their R\&D expenditures below expected levels. R\&D spending was lower by 5.3 percent in 1994 , which is equivalent to a drop of $\$ 508$ million ( $\$ 1.02$ billion) measured in 1983 (2004) dollars. If the HSA had passed, and had many biotech firms not raised significant amounts of capital just before the HSA, the change in R\&D spending could have been much greater. 
This paper is organized as follows. Section I briefly discusses the HSA and how it could affect the R\&D spending behavior of a range of firms distinguished by $R \& D$ intensity, risk, and liquidity. Testable hypotheses are proposed. Section II describes the data and presents a graphical view of the HSA's effects on stock prices. Section III presents a model of expected R\&D spending intensity, and tests the relation between HSA-related abnormal returns and firm-level $R \& D$ intensity and risk. It also tests the relation between subsequent unexpected R\&D spending intensity and HSA-related abnormal returns and risk changes. Section IV concludes the paper.

\section{The HSA and Its Potential Effects on Pharmaceutical Stock Prices and R\&D Spending}

To more precisely link the HSA to changes in firm value and risk, Section A discusses the particular parts of the act that were most relevant to pharmaceutical firms. Section B characterizes pharmaceutical firms in ways that help guide the empirical analysis that follows.

\section{A. HSA Price Control Threats}

Ellison and Mullin (2001) provide a detailed analysis of the events surrounding the HSA and describe its major provisions. Proposed universal coverage for outpatient drugs was a positive for pharmaceutical firms, but proposed purchasing groups, restrictive formularies, drug utilization reviews, and generic substitution would likely offset the benefits of universal coverage. They contend that the most important provision for pharmaceutical firms, also modeled by Abbott (1995), was price limits on new breakthrough drugs.

Grabowski and Vernon (1990) show that breakthrough drugs must earn large profits in order to cover the combined R\&D costs of many drugs that are never marketed. For the purposes of our study, this means that the proposed price limits on breakthrough drugs would likely cut the value of firms' $R \& D$ assets. In particular, firms with high $R \& D$ exposures (e.g., small 
biotechnology firms) could be expected to experience relatively large stock price changes and R\&D spending changes.

Ellison and Mullin (2001) argue convincingly that the HSA was a serious threat to the pharmaceutical industry, and that it accounted for the large negative returns experienced by the industry during 1992-1993. The industry believed that the HSA could be so ruinous that 21 large firms pledged to keep their price increases below consumer inflation in order to convince Congress that the legislation was not necessary ${ }^{3}$. But these large firms are not the most R\&D intensive and the bulk of our sample of firms did not pledge to stifle their price increases.

Price controls can affect more than just expected future profitability. They can reduce expected future return volatility, as is common for price-regulated utilities. Of course, because the HSA was not enacted, the events surrounding it could have simply created greater uncertainty about future pharmaceutical prices, increasing firm risk. Therefore, we also study the crosssectional effects of the HSA on firm risk; both systematic and total risk. We study how the levels (and changes) of firm risk during the period are related to stock price changes and subsequent R\&D spending changes.

\section{B. Expected Effects of the HSA on Stock Returns and Risk}

The firms in the pharmaceutical industry are traditionally characterized as generic, brandname, or biotech (pure research). This study, however, characterizes firms by the relative sizes of the market values of their component parts. We assume that the total market value of a firm, $V_{T}$, is composed of three parts; the value of its marketed drugs, $V_{D}$ (assets in place), the value of its R\&D portfolio, $V_{R}$ (growth opportunities), and the value of its net liquid assets, $V_{L}$. The systematic risk $\left(\beta_{T}\right)$ of the firm is a weighted average of the Capital Asset Pricing Model (CAPM) betas of the three assets:

\footnotetext{
${ }^{3}$ The Department of Justice ruled that the pledge was illegal and the Federal Trade Commission claimed that the firms were fixing prices.
} 


$$
\beta_{T}=W_{L} \beta_{L}+W_{D} \beta_{D}+W_{R} \beta_{R}
$$

where $\beta_{L}, \beta_{D}$, and $\beta_{R}$ are betas of the three assets and the weights are $W_{L}=V_{L} / V_{T}, W_{D}=V_{D} / V_{T}$, and $W_{R}=V_{R} / V_{T}$. In this formulation, the R\&D exposure of a firm is given by the product of its R\&D intensity, $W_{R}$, and sensitivity, $\beta_{R}$. (For a more formal presentation, see Appendix A.)

Because the proposed HSA mostly affected the pricing of future drug discoveries, the HSA should have primarily affected firms' R\&D portfolio values, $V_{R}$. And those values can be described as real options. Schwartz (2004) models an R\&D project as a call option, and shows how government regulation can affect its value. The expected HSA effects can be described by how price limits for future drugs affect the expected return and risk of a call option.

The underlying asset price, $S$, of an R\&D option is the present value of expected future cash flows from a new drug. Drug price constraints will reduce a drug's future cash flows, but not the expected production and marketing costs, $X$. This will reduce the in-the-moneyness $(S-X)$, and hence the value of, an R\&D call option. Further, the final passage of price regulation could lower asset return volatility, although the intervening legislative debate and uncertainty about the passage of the proposed reforms would have the opposite effect on short-run return volatility. The more $R \& D$ options a firm holds as a proportion of its total assets, the higher the R\&D intensity and the greater the HSA's expected affect. This leads to our first hypothesis.

Hypothesis 1: All else equal, the stock price response to HSA-related news releases will be negatively related to a pharmaceutical firm's $R \& D$ intensity.

Since the true $\mathrm{R} \& \mathrm{D}$ intensity, $W_{R}$, is not observable, we will use an accounting (historical) variable to capture the R\&D intensity of pharmaceutical firms. Following Chan, Lakonishok, and Sougiannis (2001), we will proxy for $W_{R}$ by capitalizing a firm's R\&D spending 
over five years ${ }^{4}$. In addition, we will use two market-based measures that influence $W_{R}$ : the preHSA stock return volatility, $\sigma_{i}$, and the change in volatility during the HSA event period, $\Delta \sigma_{i}$. The $\mathrm{R} \& \mathrm{D}$ option value is increasing in both $\sigma_{i}$ and $\Delta \sigma_{i \text {. }}$ Because high-volatility increases the expected in-the-moneyness of R\&D options, we expect the price response of firms with high pre-event $\sigma_{i}$ to be less sensitive to the proposed HSA news. Therefore, we expect the stock price response to be positively related to the pre-event stock volatility and the event-induced change in volatility.

The second important component of $\mathrm{R} \& \mathrm{D}$ exposure is the beta of the $\mathrm{R} \& \mathrm{D}$ assets, $\beta_{R}$. We know that the values of R\&D options that are well in-the-money $(S>>X)$ will be less sensitive to the HSA price threats. In contrast, marginal projects (i.e., those projects for which the R\&D asset value, $S$, is close to the cost of production facilities, $X$ ) will be more sensitive to proposed price constraints. A firm composed of mostly at-the-money or out-of-the-money R\&D projects should have a relatively high $\beta_{T}$, and be more vulnerable to the HSA price threats. Galai and Masulis (1976) show how option beta is affected by changes in the underlying asset price. Notice that the level of firm $\beta_{R}$ (and in turn $\beta_{T}$ ) measures its R\&D leverage and should be negatively associated with $S$. Although the moneyness and $\beta_{R}$ of a firm's R\&D options are not observable, the R\&D sensitivity can be partly inferred from a firm's pre-event stock beta, $\beta_{i}$, and the change in beta during the HSA event period, $\Delta \beta_{i}$. Essentially, the HSA price threats reduce moneyness and increase beta of the R\&D call option. This leads to the following hypothesis.

Hypothesis 2: All else equal, the stock price response to HSA price regulation threats will be negatively related to a firm's pre-event equity beta and the event-induced beta change.

\footnotetext{
${ }^{4}$ Their specification for capitalized R\&D (CRD) for company $i$ in year $t$ is $\mathrm{CRD}_{\mathrm{i}, \mathrm{t}}=\mathrm{RD}_{\mathrm{i}, \mathrm{t}}+0.8 * \mathrm{RD}_{\mathrm{i}, \mathrm{t}-1}+0.6 * \mathrm{RD}_{\mathrm{i}, \mathrm{t}-2}+0.4 * \mathrm{RD}_{\mathrm{i}, \mathrm{t}-3}+0.2 * \mathrm{RD}_{\mathrm{i}, \mathrm{t}-\mathrm{t}}$,
} where $\mathrm{RD}_{\mathrm{i}, \mathrm{t}-\mathrm{i}}$ is $\mathrm{R} \& \mathrm{D}$ expense for year $t-i, i=0$ to 4 . 
Hypothesis 2 simply observes that marginal R\&D projects, like out-of-the-money options, are more levered, making them riskier and more sensitive to the negative HSA effects.

Our first empirical model tests these hypotheses using cross-sectional data measured around the HSA.

$$
C A R_{i}=b_{0}+b_{i}\left(C R D T A_{i}\right)+b_{2}\left(\beta_{i}\right)+b_{3}\left(\Delta \beta_{i}\right)+b_{4}\left(\sigma_{i}\right)+b_{5}\left(\Delta \sigma_{i}\right)+\varepsilon_{i} .
$$

$\mathrm{CAR}_{i}$ (cumulative abnormal return) measures firm i's stock market value reaction to surprise announcements associated with the HSA. R\&D intensity $\left(C R D T A_{i}\right)$ is the capitalized value of firm i's R\&D spending divided by its total assets (following Chan, Lakonishok, and Sougiannis (2001)). $\beta_{i}$ and $\sigma_{i}$ are firm $i$ 's beta and return volatility, respectively, measured before the HSA. $\Delta \beta_{i}$ and $\Delta \sigma_{i}$ are changes in these variables during the HSA event period. Hypothesis 1 implies $b_{i}<0, b_{4}>0$ and $b_{5}>0$. Hypothesis 2 implies $b_{2}<0$ and $b_{3}<0$.

There are a number of potentially confounding issues to consider. The most important of these is that $R \& D$ beta is unobservable, so that it has been assumed that equity beta mirrors $R \& D$ beta. This is a reasonable assumption if firm value is largely composed of marketed drugs and $\mathrm{R} \& \mathrm{D}$ projects. But when the ratio of liquid assets, $L$, to total assets varies significantly across firms, the cross-section of equity betas and beta changes is less likely to accurately reflect $R \& D$ betas and beta changes. The same is true for volatility and volatility changes. Fixing R\&D beta and $R \& D$ return volatility, greater liquid assets imply smaller equity beta, volatility, beta changes, and volatility changes. To account for these effects, $\beta_{i}, \sigma_{i}, \Delta \beta_{i}$, and $\Delta \sigma_{i}$ are interacted with liquid assets, $L$, and the interaction variables are added to (2).

Moreover, pharmaceutical firms with long and deep R\&D pipelines tend to accumulate (excessive) liquid resources to fund those projects in the future. In a sense, liquid assets reflect future R\&D expenditures (and intensity) of the firm. High values of the interaction terms $\left(\beta_{i} x L\right)$ 
and $\left(\Delta \beta_{i} \times L\right)$ represent firms that have proportionally more marginal future R\&D projects. Since such projects are particularly vulnerable to the proposed HSA price caps, we expect the coefficients associated with these interaction terms to have negatives signs. On the other hand, high values of the interaction terms $\left(\sigma_{i} x L\right)$ and $\left(\Delta \sigma_{i} x L\right)$ represent firms that have more volatile future R\&D projects. So we expect their coefficients to be positive.

Liquidity can have behavioral effects as well as purely technical effects. In particular, managers could blunt the measured effects of the HSA if they cut back on R\&D spending since many R\&D projects will require much future spending. But Jensen (1986) suggests that firm managers with freely available cash may not act in the firm's best interest, and Guedji and Scharfstein (2004) show that high-cash biotech firms often overspend on R\&D. With respect to the HSA, liquidity provides managers with the financial slack to continue R\&D spending even if threatened price regulation makes the expected value of some R\&D spending negative. Therefore, liquidity could enhance the negative (positive) effects of $\beta_{i}$ and $\Delta \beta_{i}\left(\sigma_{i}\right.$ and $\left.\Delta \sigma_{i}\right)$ on $C A R$.

Other confounding issues are possible, but we believe less likely. The HSA proposed extended prescription coverage, hence, $R \& D$ intensive firms could benefit from greater expected unit sales. But Coulson and Stuart (1995) show that the demand for pharmaceuticals is price inelastic, making it unlikely that the decrease in profit per unit could be made up in larger volumes. Heavy lobbying by pharmaceutical firms against the HSA implies that they expected significant negative effects.

Cross-sectional variation in firm financial leverage could also account for variation in $C A R$. We consider this possibility by adding a leverage (control) variable to (2).

Finally, we also consider whether the brand-name drug firms that voluntarily constrained their price increases prior to the HSA suffered relatively large stock price declines. HSA passage could have forced them to make their pledge more permanent than the market expected. In this case, $C A R$ and a binary variable identifying price constrained firms should be negatively related. 
Alternatively, because the firms constrained prices before the HSA events, the effect of those events on them could be diluted.

Model (2) establishes the drivers of firms' stock price reactions to the HSA. Our second model tests whether firm managers, in turn, changed their R\&D spending in response to HSAinduced changes in stock prices $(C A R)$ and risk $\left(\Delta \beta_{i}\right.$ and $\left.\Delta \sigma_{i}\right)$. Negative $C A R s$ imply that investors believed that a firm's R\&D options values were more likely to fall below their R\&D expenses. Managers should react by cutting R\&D spending, either because they also believe some marginal projects are no longer worthwhile, or because they respond to signals sent by investors through stock prices. Similarly, managers could react to changes in their stocks' risk levels. A large $\Delta \beta_{i}$ implies that a firm has more marginal $R \& D$ projects, so that managers should cut $R \& D$ spending more. Conversely, a large $\Delta \sigma_{i}$ implies larger $\mathrm{R} \& \mathrm{D}$ options values, and managers should increase spending. These arguments lead to:

Hypothesis 3: All else equal, unexpected $R \& D$ spending is positively related to $C A R$ and $\Delta \sigma_{i}$, but negatively related to $\Delta \beta_{i}$.

The second empirical model tests this hypothesis.

$$
\operatorname{URDTA}_{i, t+1}=b_{0}+b_{1}\left(C A R_{i, t}\right)+b_{2}\left(\Delta \beta_{i, t}\right)+b_{3}\left(\Delta \sigma_{i, t}\right)+\varepsilon_{i, t+1} .
$$

Unexpected $\mathrm{R} \& \mathrm{D}\left(U R D T A_{i}\right)$ is firm $i$ 's unexpected $\mathrm{R} \& \mathrm{D}$ spending in the post-HSA period as a proportion of its total assets. It is a residual from a model that estimates normal or expected R\&D spending intensity (discussed in the next section). Hypothesis 3 implies $b_{1}>0, b_{2}$ $<0$, and $b_{3}>0$. 
There are again some potentially confounding issues to consider. As in (2), $\Delta \beta_{i}$ and $\Delta \sigma_{i}$ proxy for changes in $R \& D$ beta and volatility, respectively. Cross-sectional variation in the proportion of liquid assets causes beta change (volatility change) to deviate from R\&D beta change (volatility change). The issue is handled by interacting liquidity with beta change (volatility change) and adding interaction variables to (3).

The free cash flow problem discussed in Jensen (1986), and empirically supported by Guedji and Scharfstein (2004) for biotech firms, is potentially more problematic in model (3) than in model (2). Model (3) purports to explain managers' R\&D spending reactions to the HSA. Liquid assets provide managers with financial slack at a time when Lerner, Shane, and Tsai (2003) show that external financing for biotech firms had dropped sharply. They also show that some firms raised funds just before the HSA. This means that financial slack could vary crosssectionally. Managers with adequate funds may not change their R\&D spending, even if their firm's stock price, beta, and volatility change significantly. As a consequence, the relations posited in (3) may not hold.

Finally, we again account for the brand-name drug firms that voluntarily constrained price increases around the HSA. These firms may have cut R\&D more than other firms in response to the HSA. Therefore, a variable identifying price constrained firms should be negatively related to $U R D T A_{i}$. Alternatively, because the firms pledged to constrain their prices before the HSA-related events, the effect on post HSA R\&D could be negligible.

\section{The Data, the Sample, and a Graphical Illustration of HSA Effects}

\section{A. The data and the sample}

The study employs financial accounting data and stock market data for each sample firm around the period of 1992-1993, when the events associated with the HSA occurred. The accounting data, such as annual R\&D expenditures, are obtained from Standard and Poor's Compustat database. The stock market data, such as daily firm stock returns, are obtained from 
the Center for Research in Security Prices (CRSP). This limits the potential sample because both Compustat and CRSP cover few foreign firms. Nevertheless, some of the largest foreign pharmaceutical firms with significant operations in the U.S. are covered in our sample.

The sample selection process is structured to be inclusive. Unlike earlier studies, we do not focus solely on large firms. The process starts with all firms on Compustat with a North American Industry Classification System (NAICS) code of either 325412 (Pharmaceutical Preparation Manufacturing) or 325414 (Biological Product Manufacturing). Included firms must have data available for at least the years 1991-1995. This selection process results in 176 firms. Of these 176 firms, 113 also have stock returns on the CRSP database covering the period. Finally, of these 113, only two have less then eight years of accounting data on Compustat. We eliminate these firms because they do not have enough data to allow us to reliably estimate their expected R\&D spending using the model discussed below. Of the remaining 111 , only one has eight years, two have nine years, and all of the others have at least 10 years of data, including the 1991-1995 period.

The study revolves around the effects of the HSA on companies' R\&D spending decisions. This requires a standardized measure of $R \& D$ spending that allows comparisons across time and across firms of different sizes. We considered the ratio of R\&D spending to a firm's total assets $(R D T A)$ and the ratio of R\&D spending to a firm's total sales $(R D S)$. We selected $R D T A$ because it gives more reasonable figures for the firms in our sample. $R D S$ gives extreme values for those firms with little revenue. We rejected excluding these firms because this would bias the sample toward more established, low R\&D-intensive firms.

Appendix B lists the 111 firms in our sample sorted by RDTA from lowest to highest and separated into quartiles. $R \& D$, assets, and sales figures are adjusted for consumer price inflation (All Urban Consumers-All Items, Base Period 1982-84=100). The figures for each firm are calculated as an average over 1989-1991, the three-year period prior to the HSA-related events. Therefore, the RDTA figure for each company characterizes its intensity of R\&D spending before 
the price regulation debate started. The problem of extreme RDS ratios is clear, particularly in quartiles 3 and 4 . The RDTA ratios are consistently more reasonable. The Appendix also shows that not all biotech firms are high R\&D-intensive, although most are. All of the generic firms are in the lowest RDTA quartile, with the brand-name pharmaceutical firms mostly in quartiles 1 and 2.

There are surprisingly few generic firms. Of course, some of the firms that we have labeled "pharmaceutical" also produce some generics, but these are few and their primary profit generators are brand-name pharmaceuticals. Clearly, investors are willing to fund many R\&Dintensive firms but few generic firms. There are 64 biotech firms; more than ten times the number of generics.

To get a better feel for the data and the sample, consider the descriptive statistics for the study variables reported in Table I. Statistics are computed for the full sample and sub-samples of firms grouped by R\&D-to-asset quartiles. Note that the accounting variables such as $R \& D$ and Total Assets are measured for each firm with annual data averaged over 1989-1991. The returnsbased variables are measured using daily stock returns. Beta is measured using the market model with the CRSP value-weighted index. Beta and return volatility for each firm are measured over the pre-event period covering April 24, 1990 to January 10, 1992. The pre-event period directly precedes the event period (January 13, 1992 to September 29, 1993), and is selected so that it has the same number of trading days as the event period. The event period consists of 434 trading days starting five trading days before the first HSA-related event (see Table II), and ends five trading days after the last HSA-related event. Beta change (volatility change) is measured as the difference between the event period beta (volatility) and the pre-event period beta (volatility).

Because the large pharmaceutical firms mostly fall into R\&D-to-assets quartile 2, that quartile has the largest average dollar amount of $R \& D$ spending and assets, followed by quartiles 1,3 , and 4 . In deference to the wide variation in firm size, the portfolio returns in the figures below are value-weighted. 
[Table I here]

In the model section, we discussed how $R \& D$ is equivalent to a leveraged investment and that $R \& D$ intensive firms could have relatively large betas. Indeed, the average pre-event betas increase across R\&D intensity quartiles. Quartile 4 firms are about 50 percent more risky than the lowest $R \& D$ intensive firms in quartile 1 . The difference in average betas between quartiles 1 and 2 is statistically significant $(\mathrm{t}$-statistic $=2.08$, not reported in Table I). Differences between quartile 1 and the others are more highly significant. Average betas for quartiles 2 and 3 also differ $(\mathrm{t}$-statistic $=1.74)$, but the average betas for quartiles 3 and 4 are not significantly different at conventional levels.

A similar monotonic pattern is observed for average pre-event return volatilities, however, quartiles 1 and 2 (and quartiles 3 and 4) have almost the same average volatilities. Not surprisingly, F-tests (not reported in Table I) of the difference in average volatility between quartiles 1 and 2, and between quartiles 3 and 4, show no statistically significant differences. However, F-tests show that the average volatilities of the first two quartiles differ from the second two quartiles beyond the 1 percent significance level.

The average beta changes are not statistically different across quartiles, mostly because of the relatively large variation in beta changes within each quartile. This could indicate that there is large variation in firms' R\&D sensitivity to the HSA within quartile. Nevertheless, it is surprising that the first quartile has the largest average increase in beta and the fourth quartile has the smallest. The small change in beta for the high-intensity R\&D firms that make up quartile 4 can be rationalized from our discussion of model (2). These firms have relatively large liquid asset weights, which we measure as the ratio of net working capital to total assets.

Average return volatility does not change much around the HSA, except for quartile 3. Furthermore, the differences between average quartile changes are statistically insignificant, except for the difference between quartile 1 and quartile 3 . One surprise is that the average volatility falls for each quartile. The volatility decrease is consistent with the possibility that the 
market expected price regulation to reduce future cash flow volatility, even while reducing average cash flows.

The quartiles also do not differ much with respect to capital expenditure intensity, measured by the ratio of capital expense to assets. The one exception is that the average capital expenditure intensity of quartile 2 is significantly larger than those of the other three quartiles. This can be explained by the fact that the second quartile contains many large pharmaceutical firms that must spend heavily on production and office facilities. The same pattern appears for advertising intensity, where large brand-name pharmaceutical firms must spend to promote their products.

Finally, financial leverage, measured by the ratio of debt to assets, shows that the firms in the first two quartiles are more leveraged than the firms in the second two quartiles. Leverage for quartile 1 and quartile 2 does not differ significantly. The same is true for quartiles 3 and 4 . However, differences in average leverage between the first two quartiles and the second two quartiles are all significant at the 5 percent level. This reflects the fact that firms in quartiles 1 and 2 typically have significant cash flows that can be used to service debt. But, overall, none of the quartiles show high average leverage.

\section{B. A graphical illustration of the effects of the HSA on firm stock prices}

To get a general idea of the magnitude of the possible effects of the HSA on our sample firms' stock prices, we present a graphical view of the cumulative total returns one would have earned on the stocks in our sample during the period when President Clinton's healthcare and pharmaceutical reform proposals became known to investors.

Table II lists the major events that we believe were at least partial surprises to investors and that can be tied to President Clinton. Ellison and Mullin (2001) provide a more detailed description of these events in their chronology of healthcare reform. We include eleven events, starting with Clinton's January 19, 1992 announcement of a vague healthcare plan just prior to 
the New Hampshire primary, and ending with his official release of the specific plan on September 22, 1993. One can argue about which events to include. We searched for significant events Ellison and Mullin (2001) might have missed and found none. But they include Clinton's July 16, 1992 acceptance of the Democratic presidential nomination and the October 3, 1993 presentation of the plan to Congress. Because neither was a surprise, we exclude them.

We do not exclude events based on realized cumulative abnormal return. For example, we include Clinton's New York primary win because we believe investors could have been surprised by it, even though our 111 stock portfolios increased in value around that event when one might have expected a decrease.

\section{[Table II here]}

The event period starts January 10, 1992, five trading days before Clinton first announced his healthcare reform plan. We include five days before the announcement because there is often leakage of news before a formal announcement, especially with regard to political proposals. The event period ends on September 29, 1993, five trading days after Clinton publicly announced the specific health plan to be sent to Congress.

Figure 1 shows the raw stock return performance of a value-weighted portfolio of our 111 sample firms during the full event period. During the period, the portfolio value fell by about 32 percent while the overall value-weighted market portfolio increased by about 18 percent. We know from Table II that the average sample firm is riskier than the market, hence, underperforming the market by 50 percent represents unusually poor performance. After adjusting for risk using the market $\operatorname{model}^{5}$, the value-weighted portfolio of 111 stocks had a cumulative abnormal return (CAR) of -62 percent during the full event period.

\footnotetext{
${ }^{5}$ The market model is $\mathrm{R}_{\mathrm{it}}=\alpha_{\mathrm{i}}+\beta_{\mathrm{i}} \mathrm{R}_{\mathrm{mt}}+\varepsilon_{\mathrm{it}}$ where $R_{i t}$ is firm i's daily stock return on day $t, R_{m t}$ is the market return on day t represented by the CRSP value-weighted index, $\alpha_{\mathrm{i}}$ and $\beta_{\mathrm{i}}$ are ordinary least squares coefficients for firm $\mathrm{i}$, and $\varepsilon_{\mathrm{it}}$ in the error term for firm $i$ at time t. The coefficients are estimated over the 255 trading days before the event period and used to calculate, $\mathrm{A}_{\mathrm{it}}$, the risk-adjusted return on a particular day $\mathrm{t}$ for firm $\mathrm{i}$ as,
} 
[Figure 1 here]

Table II reports 11-day value-weighted CARs, covering five days before, and five days after, each of the eleven major events. The sum of the CARs over the 11 events is -45.50 percent, significant at the one percent level after accounting for cross-sectional correlation. Ellison and Mullin (2001) argue that news about the probability of price control legislation leaked out gradually over the full period, which could account for the difference between the 11 event CAR and the full period CAR (-62 percent). They attribute the negative returns during the full period to the effects of the political events leading to the HSA. This may well be the case, especially if one views the HSA as the focal point of an emerging political consensus that pharmaceutical prices should be constrained either directly or indirectly. Nevertheless, with such a long event period, accurately measuring the total effect of the HSA is problematic.

But our empirical tests do not require an accurate measure of the full effect of the HSA. We require a reasonable measure of the relative cross-sectional effects of the HSA on our sample of firms. Therefore, we use only the last four events, which are more closely tied to the HSA and occur in 1993, when Clinton is president. The sum of the four events' CARs is 19.01 percent.

To illustrate the potential relations proposed in our hypotheses, Figure 2 plots valueweighted CARs for the 111 firms stratified by RDTA into quartiles. Quartile 1 CARs are plotted as the first thin line on the graph, quartile 2 CARs are plotted as the first thick line, quartile 3 CARs are plotted as the second thin line, and quartile 4 CARs are plotted as the second thick line. The figure shows that quartiles 1 and 2 experience similar CARs over the period. Quartiles 3 and 4 start out similar but diverge somewhat later on. This is consistent with the descriptive statistics in Table II, which show that these quartile pairs are comprised of firms with some similar characteristics.

$$
A_{i t}=R_{i t}-\hat{\alpha}_{i}-\hat{\beta}_{i} R_{m t} .
$$

We calculate the compound sum of risk-adjusted daily returns during the event period for each firm, and weight that sum by each firm's total market value as a proportion of the total market value of all 111 firms. The risk-adjusted portfolio return is the sum of the 111 weighted returns. 
[Figure 2 here]

By the end of the event period, CARs in quartiles 1 through 4 are $-64.31,-58.49,-75.51$, and -92.63 percent, respectively. Except for the fact that quartile 2 CARs slightly exceed quartile 1 CARs, higher R\&D intensity is associated with lower CARs across the quartiles. This is a simple illustration of the negative relation predicted in hypothesis 1 . One reason why quartile 2 CARs could exceed quartile 1 CARs is given by hypothesis 2. Quartile 2 firms experience an average beta increase of 0.09 compared to 0.15 for quartile 1 . The larger beta change could indicate that quartile 1 firms' $R \& D$ projects were more marginal, and hence, more negatively affected by the HSA.

\section{Expected R\&D Spending Intensity and Statistical Tests}

The graphs illustrate the magnitude of the effects that the healthcare reform debate and the HSA appeared to have had on pharmaceutical firms' stock prices. The relatively large effects on the most R\&D intensive firms are consistent with the HSA's proposed price restrictions on new drugs. This section presents statistical tests of the hypotheses discussed in Section I. Section A models a pharmaceutical firm's normal (expected) R\&D spending behavior, excluding the effects of stock prices. Section B reports hypotheses test results including the relation between $C A R$ and firm R\&D assets and the relation between firms' $\mathrm{R} \& \mathrm{D}$ spending and $C A R$. The potential effects of liquidity, self-imposed price constraints, and financial leverage also are considered. Section C discusses how the HSA might have indirectly affected firms' capital expenditure and advertising because these items could be complements or substitutes for R\&D. The section ends with a discussion of the effect of the reaction of firms' stock prices after the HSA was defeated. 


\section{A. A model of expected and unexpected R\&D intensity}

To decide whether the HSA had a significant effect on firm-level pharmaceutical R\&D spending behavior, we need measures of expected $R \& D$ spending and unexpected $R \& D$ spending. As previously discussed, we use R\&D-to-Assets (RDTA) as a measure of $\mathrm{R} \& \mathrm{D}$ spending intensity. This standardized measure is better behaved for our sample than R\&D-tosales, and is more comparable across time and across firms of different sizes, than raw dollars of R\&D spending. Eberhart, Maxwell and Siddique (2004) also use RDTA to identify significant R\&D changes. Henceforth, we use RDTA and "R\&D spending" interchangeably. The HSA may not reduce the total dollar amount of R\&D spending, but firms may increase spending at a slower rate relative to asset growth. RDTA should capture such behavioral changes.

We follow earlier studies to model expected and unexpected RDTA. Because the HSA did not become law, it did not directly reduce firms' product prices, sales, cash flows, etc. Therefore, these financial accounting variables can be used to estimate a firm's expected RDTA in a particular year in the absence of the HSA. Grabowski (1968), Lichtenberg (2004), and Himmelberg (1994) used sales, cash flows, or assets. Large firms may rely on sales and cash flows, but Hall (2002) shows that small firms rely on investor financing. As they raise capital in a particular year, their current assets and working capital, and also their R\&D, increase in that year. Mikkelson and Partch (2003) document the positive contemporaneous relation between cash holdings and R\&D expenditures. Therefore, we use the following model that combines these major drivers of $\mathrm{R} \& \mathrm{D}$ spending.

$\operatorname{RDTA}_{i, t}=a_{0}+a_{i, 1}\left(\right.$ Sales $\left._{i, t}\right)+a_{i, 2}\left(\right.$ Assets $\left._{i, t}\right)+a_{i, 3}\left(\right.$ Cash Flow $\left._{i, t}\right)+a_{i, 4}\left(\right.$ Current Assets $\left._{i, t}\right)+$

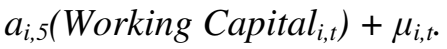

Regression model (4) relates firm i's RDTA to its sales, assets, cash flow, current assets, and working capital, all measured at time $t$. The fitted values from the regression measure a firm's 
expected RDTA. Unexpected RDTA (URDTA) for each firm $i$ in year $t$ is measured as the error term $\left(\mu_{\mathrm{i}, t}\right)$ from (4). The purpose of the model is to get an accurate prediction of R\&D based on accounting variables but not stock price changes ${ }^{6}$. If firms react to stock price changes by changing RDTA, then this change in behavior should be captured in $\mu_{\mathrm{i}, \mathrm{t}}$.

We want to capture each firm's R\&D spending behavior around the HSA, therefore, we estimate the regression separately for each firm over the years for which it has annual Compustat data during 1980-2000. Most firms have at least ten years of data during this period (one firm has eight and two have nine years). Only 22 firms have data before 1980 and 25 firms have no data after 2000 .

Table III illustrates how these variables were changing for the average firm in our sample around the time of the HSA. The variables are in real terms, where dollar figures have been adjusted for consumer price inflation (All Urban Consumers-All Items, Base Period 198284=100). The means of the variables in each year between 1989 and 1996 are presented for the full sample and for RDTA quartiles.

\section{[Table III here]}

Clearly, the industry experienced strong growth during the period. For the average firm between 1989 and 1996, R\&D increased from $\$ 64$ to $\$ 108$ million, assets increased from $\$ 729$ to $\$ 1166$ million, sales increased from $\$ 712$ to $\$ 959$ million, cash flow increased from $\$ 120$ to $\$ 184$ million, and current assets increased from $\$ 381$ to $\$ 487$ million. But working capital actually decreased from $\$ 165$ to $\$ 138$ million. Somewhat surprising is the negative return on assets in each year. This is true for each quartile, with very poor returns for quartiles 3 and 4 , which have many small, low-revenue firms. Average cash flow is negative in each year for quartiles 3 and 4 . But these quartiles still have much higher growth in the other variables than quartiles 1 and 2.

\footnotetext{
${ }^{6}$ This model provides relatively good explanatory power. The average R-Squared from this regression for the 111 firms in our sample is 0.66 .
} 
Firms in quartiles 3 and 4 rely heavily on external financing sources to fund R\&D. This can be seen in the large jump in current assets and working capital from 1990 to 1991 for both quartiles. Lerner, Shane, and Tsai (2003) document a large spike in initial public offerings and follow-on offerings for biotech firms during this period. They suggest that the subsequent sharp drop-off in external financing was due at least partly to the HSA.

Consider URDTA figures for the full sample and the quartiles. If firms reduced R\&D spending intensity in response to HSA-related stock prices declines, we should expect to see negative URDTA in 1993, or perhaps 1994 or even 1995. For the full sample, average URDTA is negative in 1993 but it is positive in 1994 and 1995. But the averages vary by quartile. Quartiles 1 and 4 have negative average URDTA in 1994 and 1995, but quartiles 2 and 3 have negative average URDTA in 1993. This illustrates how the effect could vary across different firms. Furthermore, some firms could be positively affected by the HSA and increase their RDTA in response. Indeed, 21 of the 111 firms had positive HSA-related CARs.

The final component required to test our hypotheses is a measure of HSA-related CARs. Our approach uses a conservative measure of the HSA effects on stock prices. We consider only the four events from Table II that occurred after Clinton became president in $1993^{7}$. The first event is the appointment of Hillary Clinton to head the group charged with writing the HSA. She was known to be predisposed to pharmaceutical price constraints. The second event is a speech by Clinton in which he directly stated that pharmaceutical prices were too high. The third event is the New York Times story reporting specific regulations from a leaked preliminary copy of the HSA. The fourth event is the formal release of the plan.

The combined CARs for each firm around these events measures its HSA-related CAR. CARs are estimated using the market model, with the CRSP value-weighted index return as the market return. The $C A R$ for each event includes five trading days before and five trading days

\footnotetext{
${ }^{7}$ Using CARs measured over all 11 events listed in Table II or the full event period in the empirical models produces qualitatively similar results.
} 
after the event. Each firm's model parameters are estimated over the 255 day trading period following the end of the event period (September 29, 1993) ${ }^{8}$. The average firm's HSA-related $C A R$ is -17.81 percent.

\section{B. Empirical model test results}

Empirical model (2) tests hypotheses 1 and 2, which posit that HSA-related $C A R$ can be explained by the vulnerability of firms' R\&D assets to price regulation. Empirical model (3) tests hypothesis 3, which posits that firms reacted to the negative effects of the HSA by reducing their $\mathrm{R} \& \mathrm{D}$ spending.

\section{B.1. The relation between HSA-related CARs and firms' R\&D exposures}

Table IV reports the results for the regression tests of the relations between HSA-related $C A R$ and pre-event capitalized $\mathrm{R} \& \mathrm{D}$ intensity $(C R D T A)$, pre-event equity beta $\left(\beta_{i}\right)$, beta change $\left(\Delta \beta_{i}\right)$, pre-event volatility $\left(\sigma_{i}\right)$, and volatility change $\left(\Delta \sigma_{i}\right)$. The first regression shows that $C A R s$ and CRDTA are significantly negatively related. This supports hypothesis 1 as well as Figure 2, which showed that the more R\&D-intensive firms experienced larger negative HSA-related $C A R s$. The regression also shows that both $\beta_{i}$ and $\triangle \beta_{i}$ are significantly negatively related to $C A R s$ as predicted by hypothesis 2 . Assuming that $\beta_{i}$ and $\Delta \beta_{i}$ measure $\mathrm{R} \& \mathrm{D}$ leverage, this means that firm's with more marginal R\&D assets experienced larger negative HSA-related returns. For example, the first and fourth RDTA quartile firms have average betas of 0.99 and 1.49, respectively. The -0.20 estimate on $\beta_{i}$ implies that fourth quartile firms' stocks declined by 10 percent more than first quartile firms' stocks on average, all else equal.

Finally, consistent with hypothesis $1, C A R s$ and $\sigma_{i}$ and $\Delta \sigma_{i}$ are positively related, although only the relation between $C A R$ and $\sigma_{i}$ is statistically significant. Given that first and

\footnotetext{
${ }^{8}$ We do not use the trading period before the events because this would entail using data from 1992 , when the other seven events occurred and during which Table I shows that firm betas were changing. Using the pre-event period betas give qualitatively similar results, however.
} 
fourth RDTA quartile firms have average $\sigma_{i}$ of 0.035 and 0.051 , respectively, the 7.22 estimate on $\sigma_{i}$ implies that fourth quartile firms' stocks declined by about 12 percent less than first quartile firms' stock on average, all else equal. These results imply that the stock price of a firm with a 1.49 beta and a 0.035 volatility would decline by about 22 percent in response to the HSA, all else equal.

\section{[Table IV here]}

As discussed in Section I, subsection $\mathrm{B}$, the relations between CARs and $\beta_{i}, \Delta \beta_{i}, \sigma_{i}$ and $\Delta \sigma_{i}$ could be affected by the variation in liquid asset intensity across firms. To consider this possibility, we interact a liquid asset intensity variable $(L)$ with these variables, and add the interaction variables to the regression. $L$ is measured as the ratio of working capital to total assets.

The second regression shows that the relations between $C A R$ and $\beta_{i}, \Delta \beta_{i}, \sigma_{i}$ and $\Delta \sigma_{i}$ are all statistically insignificant after accounting for cross-sectional liquidity differences. But all of the estimates on the interacted variables are significant. The negative estimates on $\left(\beta_{i} \times L\right)$ and $\left(\Delta \beta_{i} \times L\right)$ imply that investors believed that high-liquidity-high-beta (or beta change) firms would be most negatively affected by the HSA. Conversely, they believed high-liquidity-high-volatility (or volatility change) firms would be least negatively affected or actually positively affected. This could simply be because the interacted variables better represent firms' $R \& D$ asset betas and volatilities. Alternatively, it could reflect investor concerns about R\&D spending by managers in the face of potential price constraints.

These results can be interpreted from a real options perspective. $\beta_{i}$ and $\Delta \beta_{i}\left(\sigma_{i}\right.$ and $\Delta \sigma_{i}$ ) measure the potential negative leverage (volatility) effects of the HSA. Those effects are more apparent once liquidity is considered. Ample liquidity allows managers of high $\beta_{i}$ firms to fund R\&D that investors find unattractive due to the HSA, hence, high-liquidity high-beta firms' stock prices fall considerably. Conversely, a liquidity constraint could actually have a positive effect on these firms' stocks. The reverse is true for firms with high-volatility R\&D projects, where 
financial slack allows those valuable projects to be funded, even if external financing dries up due to the HSA.

The third regression includes a leverage variable, where firm leverage is measured by the ratio of total debt to total assets. The estimate on leverage is statistically insignificant. Furthermore, none of the other estimates change much. This means that none of the other variables in the regression are picking up the effects of financial leverage as opposed to $R \& D$ leverage.

Finally, the last regression includes a variable to test whether firms that pledged to keep price increases low experienced relatively low returns. Twenty-one established firms pledged by mid-1993 to keep their drug price increases below the general consumer price inflation. Of the 21 firms listed in Ellison and Wolfram (2001), ten are part of our sample ${ }^{9}$. The price constraint dummy $\left(P C D_{i}\right)$ variable equals 1 if firm $i$ pledged to keep its price increases below the inflation rate, and equals zero otherwise. The point estimate on $P C D$ is negative but it is not statistically significant.

B.2. The relation between firms' subsequent R\&D spending and the HSA price threats

Hypothesis 3 posits that the HSA's effects on firms' stock prices and risks will affect their subsequent $R \& D$ spending. Table $V$ reports the regression tests of empirical model (3) for the relations between unexpected $\mathrm{R} \& \mathrm{D}$ intensity $(U R D T A)$ and $C A R, \triangle \beta_{i}$, and $\Delta \sigma_{i}$. Because $C A R$ is measured in 1993, and managers might not respond immediately by changing current R\&D budgets, results are presented for 1993, 1994, and 1995. Results for the first three regressions show that URDTA and CAR are positively related, although only the 1994 effect is statistically

\footnotetext{
${ }^{9}$ Our sample includes Abbott Labs, Bristol-Meyers Squibb, Eli Lilly, Glaxo, Johnson \& Johnson, Merck, Pfizer, SmithKline Beecham, Warner-Lamber and Wyeth-Ayerst (American Home Products). The other firms are Ciba-Geigy, Dupont-Merck, G.D. Searle, Genentech, Hoechst-Roussel, Hoffmann-La Roche, Knoll, Marion Merrell Dow, Syntex, Upjon, and Zeneca. These 11 firms do not have the necessary data.
} 
significant. Given that most firms had negative CARs, this implies that the HSA induced firms to cut their R\&D intensity in the year following the HSA-related events.

URDTA and $\triangle \beta_{i}$ also are positively related, with both the 1993 and 1994 estimates statistically significant. But hypothesis 3 predicts a negative relation because, from an options perspective, the average increase in $\beta_{i}$ for the sample firms implies increased R\&D leverage, i.e., more marginal projects. And Table IV shows that the larger the $\Delta \beta_{i}$, the greater the decline in a firm's stock price. The optimal response by managers should be to reduce R\&D spending. But the positive estimate implies that high $\Delta \beta_{i}$ firms actually increased their R\&D spending (or decreased it less than expected).

The weakly-significant positive relation between URDTA and $\Delta \sigma_{i}$ for the 1995 regression is consistent with our hypothesis. Because $\sigma_{i}$ decreased on average, firms' R\&D option values should have decreased, all else equal. In response, managers should reduce R\&D spending, which is consistent with the positive estimate.

The effects of firm liquidity on managers' R\&D spending decisions can help explain these mixed results. The fourth regression in Table V shows that firm liquidity had a significant effect on how managers responded to the HSA. Again, $L$ is interacted with the risk change variables and these new variables are added to the regression. The relations between URDTA and $\Delta \beta_{i}$ and $\Delta \sigma_{i}$ are now insignificant.

The positive estimate on $\left(\Delta \beta_{i} \times L\right)$ is significant. This implies that high-liquidity-highbeta-change firms tended to increase R\&D spending in response to the HSA rather than decrease it as predicted. This could reflect suboptimal behavior on the part of managers of liquid firms whose $R \& D$ asset values were relatively sensitive to the HSA. The effect is not purely liquidity driven because if $L$ is included separately in the regression, it is not statistically significant, although the point estimate is positive. It is the combination of high-liquidity and high-beta that drives the result. Of course, Table IV shows that high-liquidity-high-beta firms also suffered 
greater stock price losses. Investors could have expected suboptimal R\&D spending behavior from liquid high-beta firms, hence, they cut their stock prices. The positive estimate on $\left(\Delta \sigma_{i} x L\right)$ is insignificant.

The last regression in Table V includes the price constraint dummy $(P C D)$ variable to test whether firms that pledged to constrain price increases reduced $R \& D$ spending relative to the other firms in the sample. The $P C D$ estimate is positive but insignificant. But this is because pricing constraints likely reduced these firms' sales, cash flows, etc. Because (4) strips the influence of these variables from URDTA, it is not surprising that URDTA and PCD are unrelated.

A better regression test of whether self-imposed price constraints affected firms' R\&D spending uses the predicted values (ERDTA) from (4) instead of URDTA. When we re-estimate the last regression in Table $\mathrm{V}$ using ERDTA as the dependent variable, the estimate on PCD is negative and significant at the five percent level ${ }^{10}$. The estimate is also significant if we use ERDTA measured in 1993 or 1995 . But using 1994 data produces the largest negative estimate. This is consistent with Ellison and Wolfram (2001) who show that the firms' self-imposed price restrictions were most evident in their 1994 drug prices.

We also considered whether financial leverage had any impact on the results. Highleverage could have constrained managers' $R \& D$ spending flexibility. We added a total-debt-toassets variable to each regression but none of the leverage estimates were significant (not shown). This is not surprising given the low debt levels of the sample (see Table I) and results from Table IV that show no significant relation between leverage and $C A R$.

Finally, we estimate the magnitude of the effect that the HSA had on firm R\&D. From Table II, the average firm experienced a -17.81 percent HSA-related return. Given the 1994 estimate of 0.09 for the relation between URDTA and CAR, the average firm decreased their RDTA by about 0.016 below its expected level. With the average RDTA of about 0.30 in 1994 (see Table III), this is about a 5.3 percent decline. This is equivalent to about $\$ 508$ million ( $\$ 1.02$

\footnotetext{
${ }^{10}$ These results are available upon request.
} 
billion) in 1983 (2004) dollars. This probably underestimates the effect because it assumes that only 1994 R\&D was affected and excludes the effects of self-imposed price constraints.

\section{The HSA effects on capital expenditures and advertising}

The HSA apparently affected firms' R\&D spending decisions. Spending on related items could also be affected by the HSA if the items are complements or substitutes for R\&D. Two relevant items are capital expenditure and advertising. We reran the regressions in Table $\mathrm{V}$ above using unexpected capital expenditure intensity (UCAPEXTA) and unexpected advertising intensity (UADVTA) in place of URDTA. UCAPEXTA and UADVTA were estimated using the same approach as URDTA. Given the limited statistical significance or sample sizes for these regressions, we only summarize the results here (available upon request).

All of the sample firms report capital expenditure in each year so the regression sample size is 111 firms. Similar to what we find for URDTA, we find that UCAPEXTA is positively related to $C A R$ and $\triangle \beta_{i}$ but the size and statistical significance of the estimates is smaller. This

makes sense if R\&D and CAPEX are weak complements. With lower R\&D spending, one would expect less need for plant and equipment, but spending on these items is probably less flexible.

Unlike CAPEX and R\&D, firms are not required to report advertising as a separate item, consequently, only 51 sample firms report advertising expense. Nevertheless, with the available sample we find that $U A D V T A$ is negatively related to HSA-related returns. Although statistically insignificant unless data for all three years are pooled, the negative relation between UADVTA and $C A R$ is intriguing. The results suggest that $\mathrm{R} \& \mathrm{D}$ and advertising are weak substitutes. This means that firms may respond to prospective price regulation by reducing $R \& D$ and increasing advertising. This strategy makes sense because advertising supports currently marketed drugs whose prices are already set, while $R \& D$ supports future drugs whose prices could be constrained. 
Finally, consider Figure 3 which plots the cumulative value-weighted CARs of the stocks in each RDTA quartile over a post-HSA period. Like the HSA event period, it includes 434 trading days, but starts on September 30, 1993 (the day after the HSA event period ends) and ends on June 20, 1995. The CARs are based on the market model using the CRSP value-weighted index return as the market return. Each firm's model parameters are estimated over the 255 day trading period following June 20, 1995.

The figure illustrates an interesting dynamic. As Ellison and Mullin (2001) note, the HSA lost political momentum shortly after it was released. The figure shows that each quartile of stocks rallied as the HSA lost its support, outperforming the market through the beginning of February 1994. But by the time Senator Bob Dole pronounced the HSA "dead" on March 2, 1994, all of the quartiles had lost their gains.

[Figure 3 here]

By the time Congress officially shelved the HSA on July 21, 1994, a clear dichotomy had emerged in the industry. The high R\&D intensity quartiles 3 and 4 plunged. Low R\&D intensity quartile 1 fell to a lesser extent. But quartile 2, that contains most of the brand-name firms, regained its losses and started to outperform the market.

A full explanation of this dichotomy is beyond the scope of this paper. But we conjecture that the HSA did indeed have long-term effects on the pharmaceutical industry even though it never passed Congress. Giaccotto, Santerre, and Vernon (2005) illustrate how the real price of pharmaceuticals increased steadily from 1980 through 1992, but remained constant from 1993 through 1997. Large brand-name firms could fair comparatively well under these conditions as they increased advertising to support the value of their marketed drugs. But generic firms relying on price competition, and biotech firms relying their $R \& D$ project values, could fair poorly. If the HSA marked the beginning of implicit pricing limitations, brand names could have become more valuable while $R \& D$ became less valuable. 


\section{Conclusion}

Recent research shows that $R \& D$ spending creates $R \& D$ assets that investors impound into stock prices. This study considers whether managers respond to large decreases in stock prices (and presumably R\&D asset values) by cutting back R\&D spending. We use the Clinton Administration's Health Security Act (HSA) as a natural experiment to show that pharmaceutical firms, threatened by regulations that would reduce $R \& D$ values, cut their $R \& D$ spending by about five percent ( $\$ 1$ billion in current dollar terms).

Events leading up to the formal presentation of the HSA to Congress in late 1993 could be traced as far back as the Democratic primaries in early 1992. We show graphically that pharmaceutical company stocks sustained significant price declines from then until late 1993. The average firm experienced a -38 percent return during the period (-62 percent risk-adjusted) while the market index earned 18 percent. But relatively $R \& D$ intensive firms suffered much larger losses on average. After the HSA was defeated in Congress, the industry as a whole rallied for a few months, but soon after, the R\&D intensive firms again suffered large stock price losses. Only brand-name firms enjoyed risk-adjusted gains.

Although the HSA appeared to have a substantial negative impact on stock prices, the relatively small R\&D decrease could reflect the fact that the HSA never became law. Also, many R\&D leveraged firms happen to have raised much of their capital just before the HSA-related events began, hence, they could maintain R\&D spending even as their stock prices sank and external funding dried up.

Finally, we find that firms reduced their capital expenditures in response to stock price declines, but the effects are smaller and less statistically significant than for R\&D spending. Based upon limited data, we find the opposite for advertising spending although the effects are usually statistically insignificant. This suggests that some firms may have responded to the HSA 
by reallocating resources from $R \& D$ to advertising. This strategy supports current products with known prices over future products with potentially constrained prices. 


\section{References}

Abbott, Thomas A., 1995, Price regulation in the pharmaceutical industry: Prescription or placebo?, Journal of Health Economics 14, 551- 565.

Acemoglu, Daron and Joshua Linn, 2004, Market Size in innovation: Theory and evidence from the pharmaceutical industry, Quarterly Journal of Economics 119, 1049-1090.

Brown, Stephen J. and Jerold B. Warner, 1980, Measuring security price performance, Journal of Financial Economics 8, 205-258.

Chan, Louis K. C., Josef Lakonishok, and Theodore Sougiannis, 2001, The stock market valuation of research and development spending, Journal of Finance 56, 2431-2456.

Coulson, E. N. and Stuart, B. C., 1995, Insurance choice and the demand for prescription drugs, Southern Economic Journal 61, 1146-1157.

Durnev, Art, Randall Morck, and Bernard Yeung, 2004, Value-enhancing capital budgeting and firm-specific stock return variation, Journal of Finance 59, 65-106.

Eberhart, Allan C., William F. Maxwell, and Akhtar Siddique, 2004, An examination of longterm stock returns and operating performance following R\&D increases, Journal of Finance 59, 623-650. 
Ellison, Sara F. and Catherine Wolfram, 2001, Pharmaceutical prices and political activity, Massachusetts Institute of Technology Working Paper.

Ellison, Sara Fisher, and Wallace P. Mullin, 2001, Gradual incorporation of information: Pharmaceutical stocks and the evolution of President Clinton's health care reform, Journal of Law and Economics 44, 89-130.

Finkelstein, A., 2004, Static and dynamic effects of health policy: evidence from the vaccine industry, Quarterly Journal of Economics 119, 527-564.

Galai, D., and R.W. Masulis, 1976, The option pricing model and the risk factor of stock, Journal of Financial Economics 3, 53-82.

Giaccotto, Carmelo, Rexford Santerre, and John Vernon, 2005, Drug prices and research and development investment behavior in the pharmaceutical industry, Journal of Law and Economics $48,195-214$.

Guedj, Ilan and David Scharfstein, 2004, Organizational scope and investment: Evidence from drug development strategies and performance of biopharmaceutical firms, MIT working paper.

Grabowski, Henry, 1969, The determinants of research and development: A study of chemical, drug, and petroleum industries, Journal of Political Economy 76, 292-306.

Grabowski, Henry and John Vernon, 1990, A new look at the returns and risks to pharmaceutical R\&D, Management Science 36, 804-821. 
Hall, Bronwyn, 2002, The financing of research and development, Oxford Review of Economic Policy 18, 35-51.

Himmelberg, Charles P., and Bruce C. Petersen, 1994, R\&D and internal finance: A panel study of small firms in high-tech industries, Review of Economics and Statistics 76, 38-51.

Hovey, Hollister, 2004, Big pharma courts rivals of generic drugs, Wall Street Journal, August 11.

Jensen, Michael C., 1986, Agency costs of free cash flow, corporate finance, and takeovers, American Economic Review 76, 323-330.

Lerner, Josh, Hilary Shane, and Alexander Tsai, 2003, Do equity financing cycles matter? evidence from biotechnology alliances, Journal of Financial Economics 67, 411-446.

Lichtenberg, Frank R., 2004, Public policy and innovation in the U.S. pharmaceutical industry, in Public policy and the Economics of Entrepreneurship, eds. Douglas Holtz-Eakin and Harvey S. Rosen, MIT Press, Boston.

Mikkelson, Wayne H. and M. Megan Partch, 2003, Do persistent large cash reserves hinder performance?, Journal of Financial and Quantitative Analysis 38, 275-294.

Schwartz, Eduardo S., 2004, Patents and R\&D as real options, Economic Notes 33, 23-41.

Tessoriero, Heather, 2004, Torrid drug price increases pause, Wall Street Journal, December 6, A3. 
Vernon, John, 2005, Examining the link between price regulation and pharmaceutical R\&D investment, Health Economics 14, 1-16.

Vernon, John, 2003, Simulating the impact of price regulation on R\&D innovation, Pharmaceutical Development and Regulation 1, 55-65. 


\section{Appendix A}

A firm's total market value, $V_{T}$, is composed of its net liquid assets, $V_{L}$, which are raised from investors or generated and retained from past drug sales, the present value of its marketed drugs, $V_{D}$, and the value of its R\&D portfolio, $V_{R}$.

$$
V_{T}=V_{L}+V_{D}+V_{R} .
$$

For simplicity, assume that the firm's R\&D portfolio is a single project, which can be described as a call option. If it chooses to, the firm can spend $E$ dollars on R\&D and receive a call option on the production of a new drug. The value of the project, $V_{R}$, is

$$
V_{R}=c\left(S, \sigma_{s}, X, T, r\right)-E,
$$

where $c(\bullet)$ is a function defining the value of a call option on a new drug with an expected net present value of future cash flows of $S$, a percent volatility for $S$ of $\sigma_{s}$, and a fixed investment cost to build a production plant of $X$ at time $T$ in the future. The risk-free rate of return is $r$.

The firm's expected stock return (ignoring debt) is,

$$
k_{T}=W_{L} k_{L}+W_{D} k_{D}+W_{R} k_{R}
$$

where $W_{L}=V_{L} / V_{T}, W_{D}=V_{D} / V_{T}, W_{R}=V_{R} / V_{T}$, and $k_{L}, k_{D}$, and $k_{R}$ are the expected returns on liquid assets, marketed drug assets, and R\&D assets, respectively. 
The systematic risk $\left(\beta_{T}\right)$ of the firm is a weighted average of the Capital Asset Pricing Model (CAPM) betas of the three assets;

$$
\beta_{T}=W_{L} \beta_{L}+W_{D} \beta_{D}+W_{R} \beta_{R}
$$

We assume that $\beta_{L}=0 . \beta_{\mathrm{D}}$ is likely to be smaller than $\beta_{R}$ because the $\mathrm{R} \& \mathrm{D}$ drug involves a future payment for fixed costs of production facilities and product launch. This future payment is equivalent to financial leverage, which increases beta. Assuming that the firm's capital structure is constant over time, then $\beta_{D}<\beta_{R}$. But $\beta_{D}$ and $\beta_{R}$ could be similar except that $\beta_{R}$ is a leveraged version of $\beta_{D}$. Firms often specialize, developing and producing drugs in relatively narrow therapeutic areas. Therefore, both the marketed drug and R\&D drug could have similar cash flow properties.

Because the HSA sought to regulate new drug prices, R\&D-intensive firms (large $W_{R}$ ) should be most affected, all else equal ${ }^{11}$. But this assumes a homogeneous distribution of $R \& D$ project characteristics across firms. In reality, some firms will have more marginal R\&D projects that are more sensitive to the HSA.

One way to measure a particular firm's R\&D sensitivity is to consider their stock risk and volatility from a real options perspective. First, marginal projects can be defined by the difference between the R\&D asset value and the cost of production facilities, $(S-X)$, that is, how far a project is "in-the-money." $(S-X)$ should be negatively associated with $\beta_{R}$. Recall that the level of firm $\beta_{R}$ (and in turn $\beta_{T}$ ) measures its R\&D leverage. A firm composed of mostly at-the-money or out-of-the-money R\&D projects should have a relatively high $\beta_{T}$, and be relatively sensitive to the

\footnotetext{
${ }^{11} V_{R}$ and $W_{R}$ probably decline because a call option value declines with the underlying asset's value $(S) . S$ declines because expected drug revenues fall assuming inelastic demand (see Coulson and Stuart, 1995), while production costs stay constant. A capped price could be less volatile than a free-market price, leading to a less volatile underlying asset value. This reduced volatility also decreases the R\&D call option value.
} 
effects of the HSA. Conversely, the level of asset volatility, measured by $\sigma_{s}$, implies larger R\&D option values and less sensitivity to the HSA, all else equal (see Galai and Masulis (1976)).

The changes in risk and volatility can also help identify the most sensitive firms. Consider first how $\beta_{T}$ should change due to the HSA. Using (4a) and denoting the HSA price regulation effect as " $p$ ", the change in the holding company's beta is:

$$
\frac{\partial \beta_{T}}{\partial p}=W_{L} \frac{\partial \beta_{L}}{\partial p}+\frac{\partial W_{L}}{\partial p} \beta_{L}+W_{D} \frac{\partial \beta_{D}}{\partial p}+\frac{\partial W_{D}}{\partial p} \beta_{D}+W_{R} \frac{\partial \beta_{R}}{\partial p}+\frac{\partial W_{R}}{\partial p} \beta_{R}
$$

Because $\beta_{L}=0$ and does not change, the first two terms on the right-hand-side of (5a) disappear. Similarly, the HSA should have little effect on $\beta_{D}$ because currently marketed drug prices would not be regulated; therefore, the third term disappears. The fourth and sixth terms represent the effects on $\beta_{T}$ when the relative values of the marketed drugs and R\&D change. Their combined effects on $\beta_{T}$ are likely to be negative on net. To see this, recall that $\beta_{R}>\beta_{D}$. Because the regulation will negatively affect $R \& D$ value, but have little effect on the marketed drug's value, the weight on the marketed drug will increase and the weight on $R \& D$ will decrease, therefore, $\frac{\partial W_{D}}{\partial p} \beta_{D}+\frac{\partial W_{R}}{\partial p} \beta_{R}<0$. That is, the marketed drug's (R\&D) smaller (larger) beta is weighted more (less) so that the firm's weighted average beta is smaller.

The fifth term in (5a) represents the HSA's effect on the risk of R\&D. There are two relevant effects derived for call options in Galai and Masulis (1976). First, price constraints will reduce $\mathrm{R} \& \mathrm{D}$ asset value $(S)$, and this will decrease the call value and increase $\beta_{R}$. More important, for those firms where $(S-X)$ is small, $\beta_{R}$ should change the most. That is, the betas of the firms with the greatest $\mathrm{R} \& \mathrm{D}$ leverage (more marginal projects) should also have the largest $\beta_{R}$ changes. The value of their $R \& D$ projects should fall the most, all else equal, and their $R \& D$ spending should fall the most (assuming that management responds to stock price changes). 
Variation in $W_{L}$ complicates a cross-sectional analysis. Two otherwise identical firms with significantly different $W_{L}$ will have different $\beta_{T}$ changes. The firm with the larger $W_{L}$ will have a smaller $\beta_{T}$ change and stock price change because a larger $W_{L}$ implies a smaller $W_{R}$, all else equal. That is, large liquid asset holdings cushion the effects of the HSA on firm risk and stock price. Hence, our analysis controls for cross-sectional variation in $W_{L}$.

An analysis of the HSA-induced change in $\sigma_{\text {s }}$ proceeds in the same way but has opposite implications. If the HSA increases $\sigma_{s}$, the R\&D asset value increases, all else equal. However, price regulation, such as that for electric utilities, usually leads to lower but less volatile prices. In any case, HSA-induced stock price change and R\&D change should be positively related to the change in $\sigma_{s}$. 


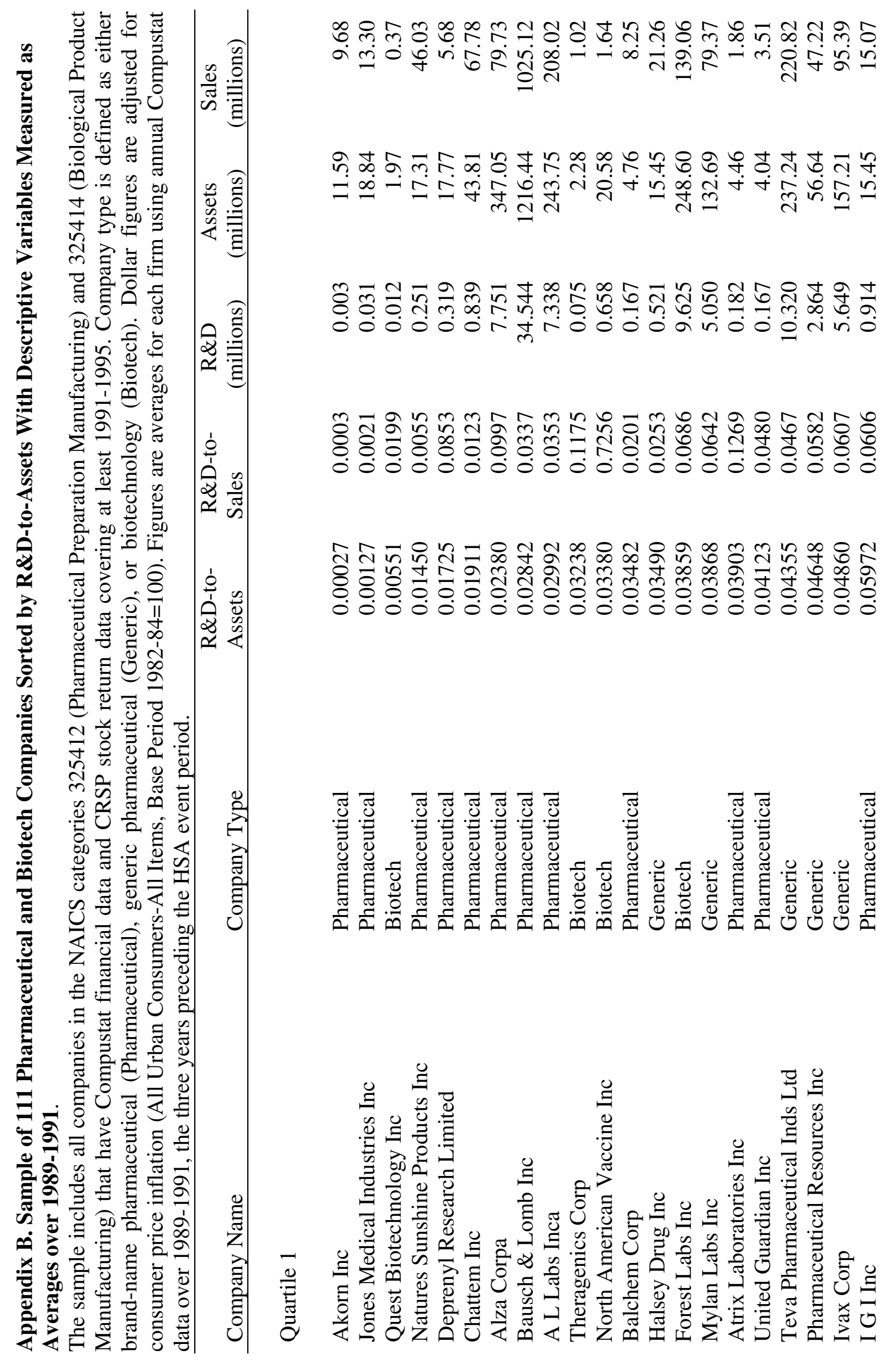




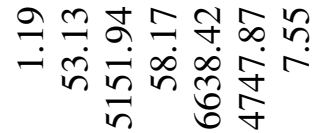

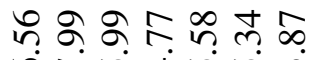

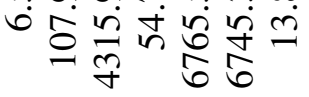

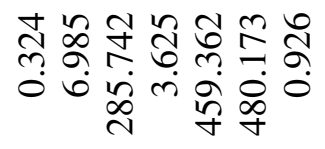

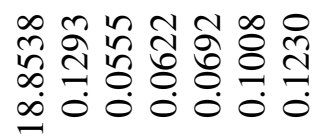

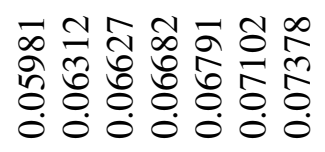

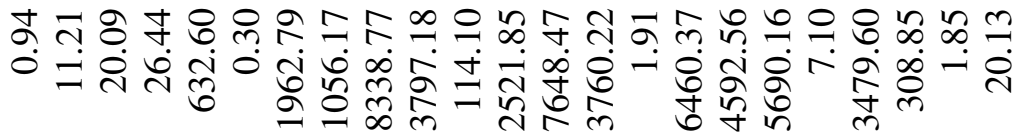

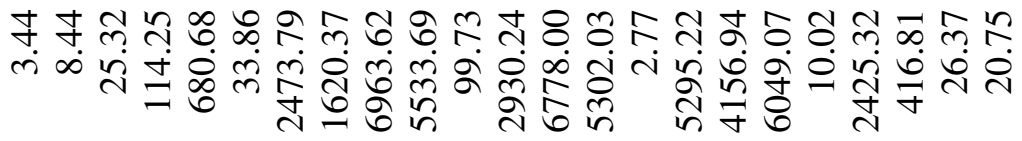

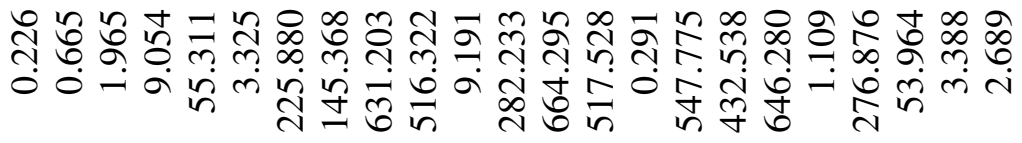

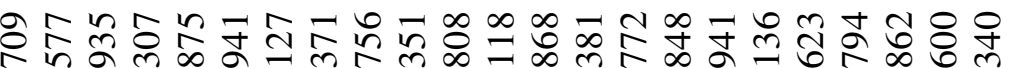
त̂

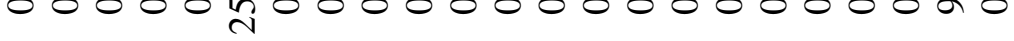

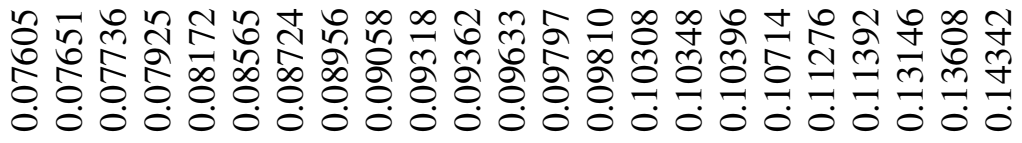
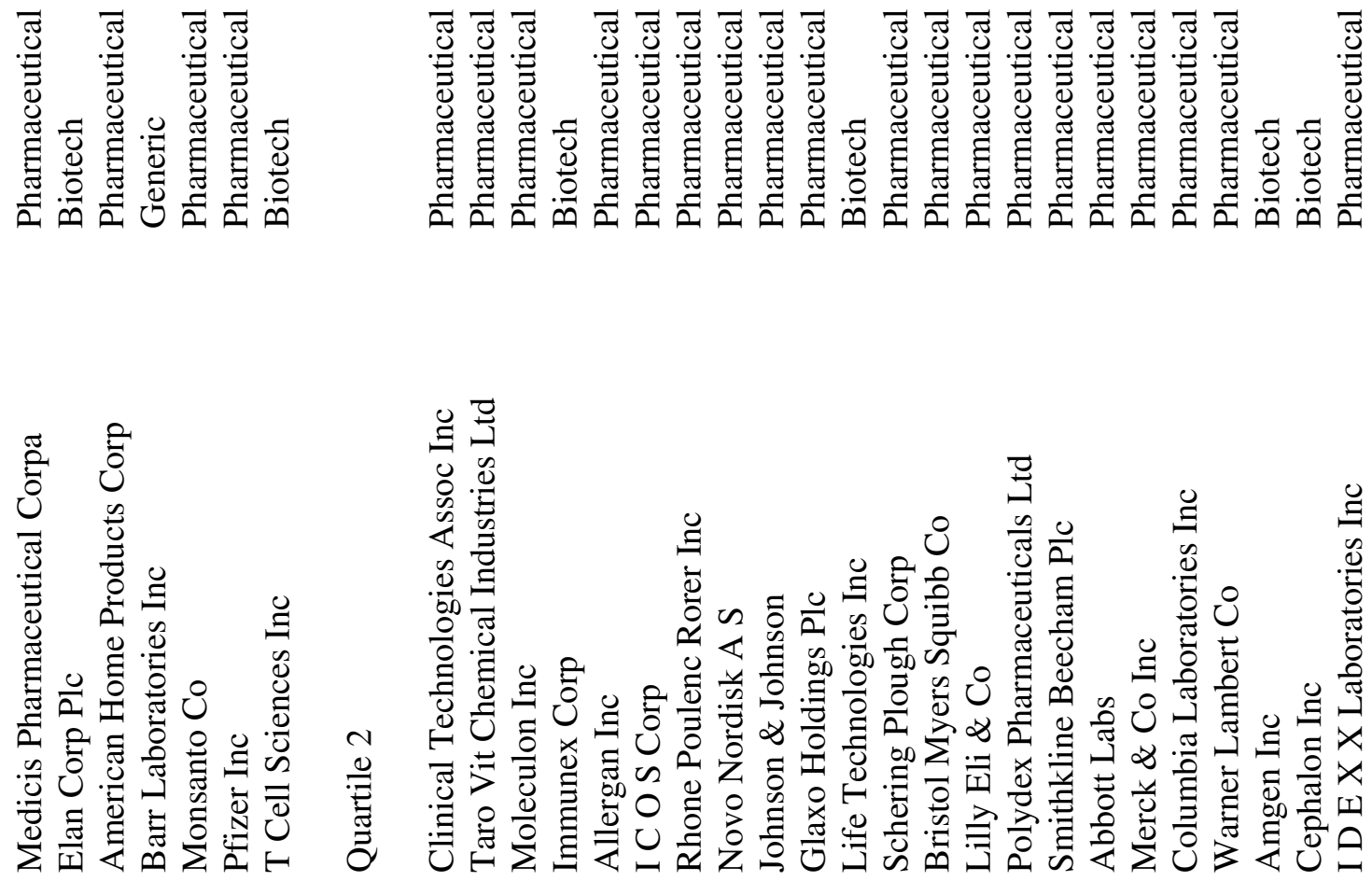


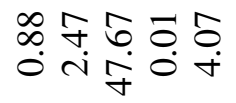

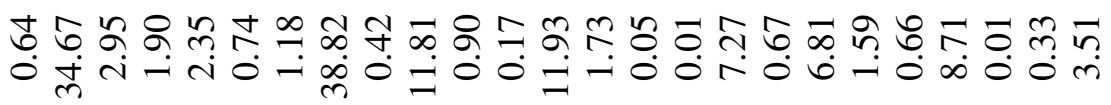

ต뉴을

$\dot{m} \stackrel{4}{4} 0$ in

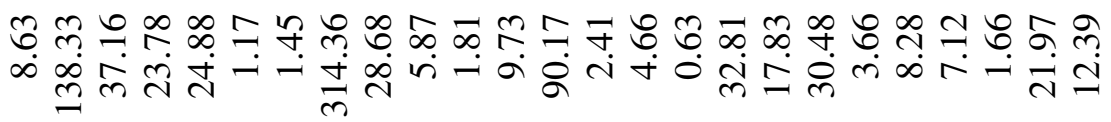

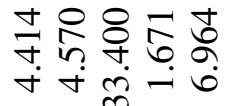

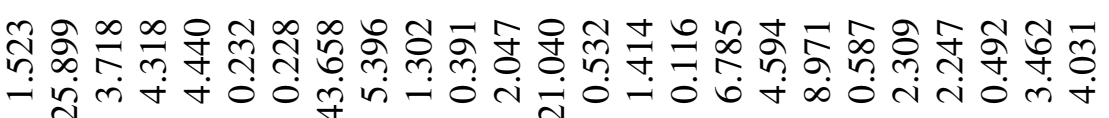

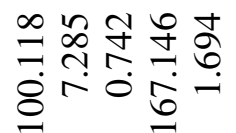

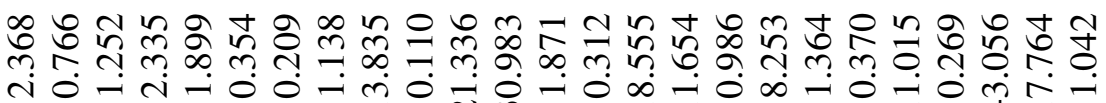

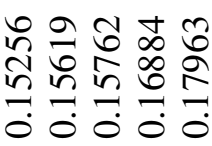

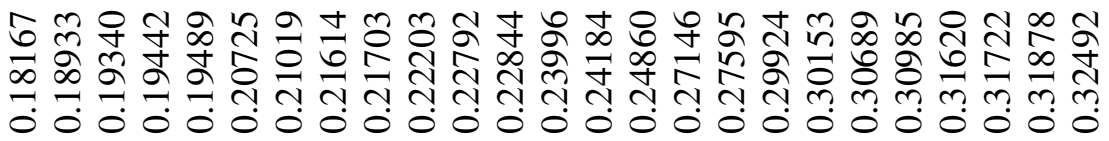
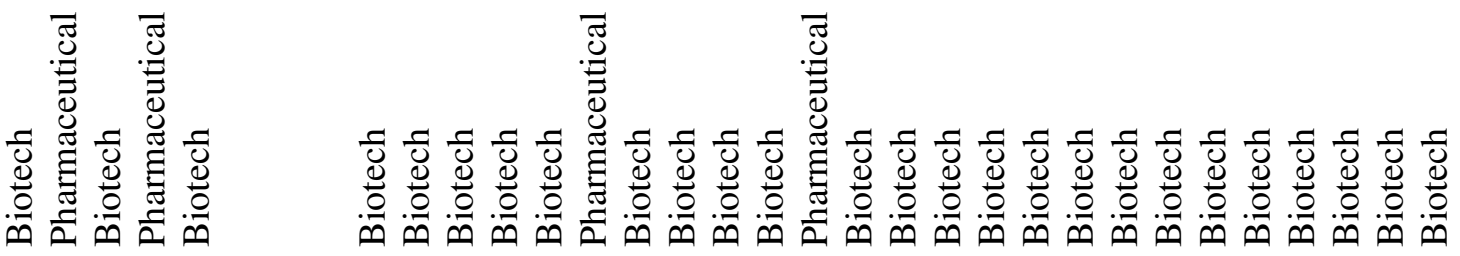

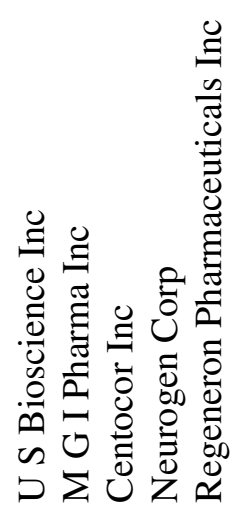

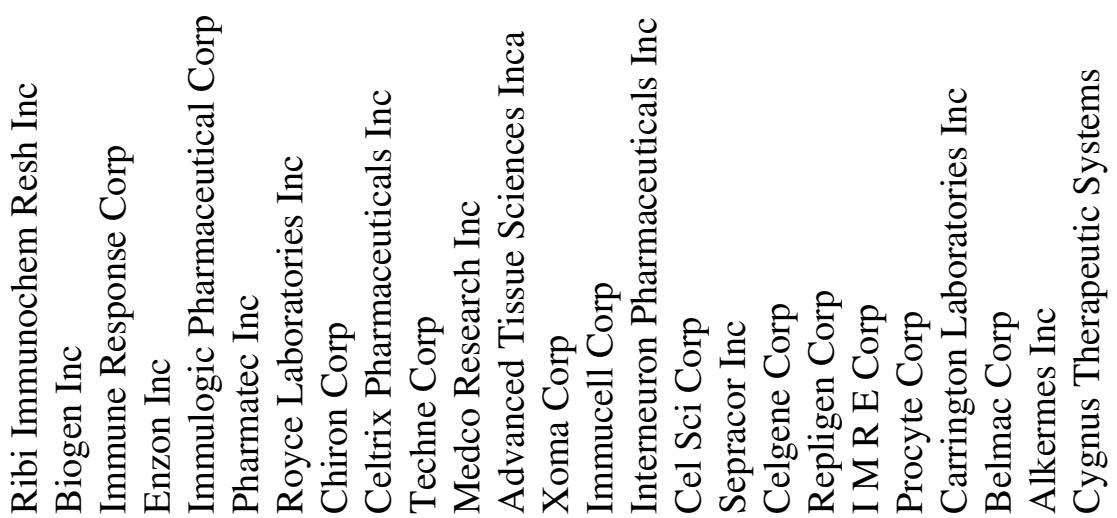




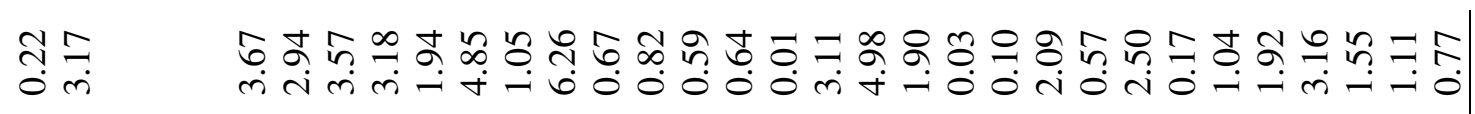

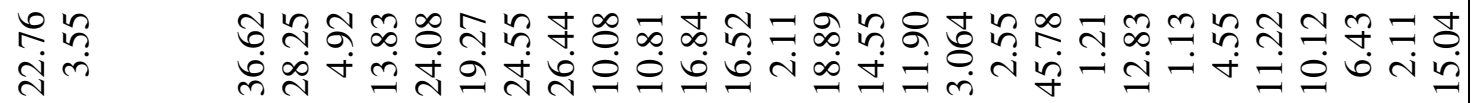

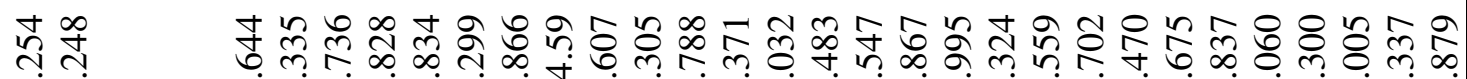

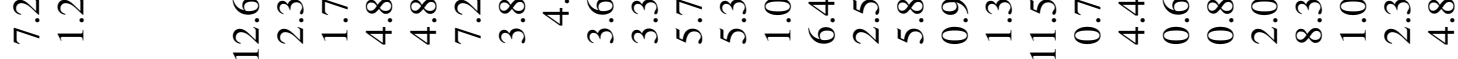

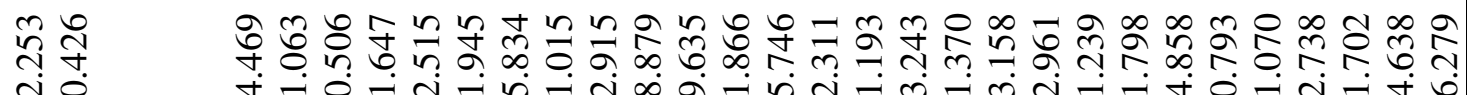
gुㅇำ

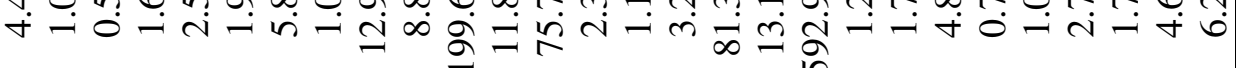

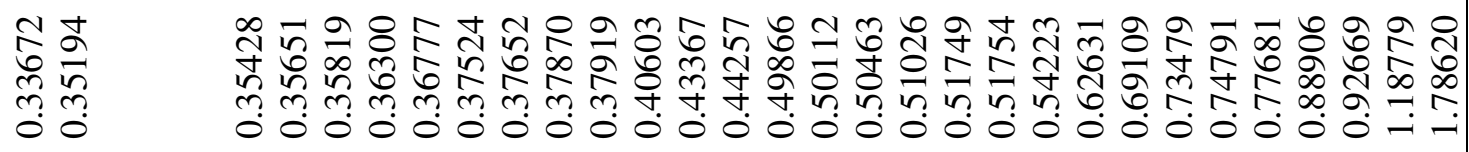

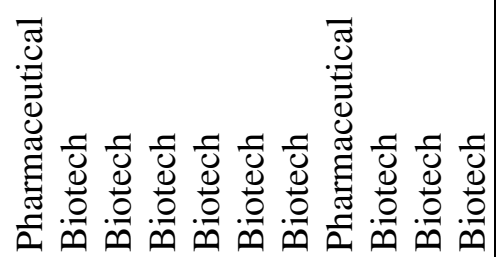


Table I. Descriptive Statistics for Study Variables for the Full Sample and By R\&D-to-Assets Quartiles.

Each firm observation for R\&D, R\&D-to-Assets, Total Assets, Capital Expense-to-Assets, Advertising-toAssets, and Debt-to-Assets is measured as an average using annual Compustat data over 1989-1991, the three year period preceding the HSA event period. Dollar figures are adjusted for consumer price inflation (All Urban Consumers-All Items, Base Period 1982-84=100). Beta and return volatility for each firm is measured using daily CRSP returns over the pre-event period covering April 24, 1990 to January 10, 1992. Beta change and volatility change are measured as differences between betas and volatilities measured over the event period (January 13, 1992 to September 29, 1993) and the pre-event period. The event period consists of 434 trading days starting five trading days before the first HSA-related event (see Table II) and ends five trading days after the last HSA-related event. The pre-event period consists of the 434 trading days preceding the event period. Firms are ranked by R\&D-to-Assets and grouped into quartiles. Except for the advertising, the full sample includes 111 firms, and quartiles 1, 2, and 4 include 28 firms. Quartile 3 includes 27 firms. For advertising-toassets the sample is limited to 51 firms, with quartiles 1,2,3, and 4 having 17, 20, 11, and 3 firms, respectively.

\begin{tabular}{ccc}
\hline Variable & Mean & Std. Dev \\
\hline R\&D (millions) & & \\
Full Sample & 60.1482 & 154.9833 \\
Quartile 1 & 47.3005 & 130.8406 \\
Quartile 2 & 181.3749 & 242.9518 \\
Quartile 3 & 5.8609 & 9.6579 \\
Quartile 4 & 4.1176 & 3.1115 \\
& & \\
Total Assets (millions) & & \\
Full Sample & 661.3324 & 1711.8500 \\
Quartile 1 & 743.8590 & 1888.0700 \\
Quartile 2 & 1833.1300 & 2471.4700 \\
Quartile 3 & 31.7168 & 63.9066 \\
Quartile 4 & 14.1359 & 11.0630
\end{tabular}

Pre-event Period Beta

$\begin{array}{lll}\text { Full Sample } & 1.2763 & 0.6128 \\ \text { Quartile 1 } & 0.9883 & 0.3281 \\ \text { Quartile 2 } & 1.2667 & 0.5391 \\ \text { Quartile 3 } & 1.3697 & 0.6578 \\ \text { Quartile 4 } & 1.4841 & 0.7584\end{array}$

Beta Change

$\begin{array}{lll}\text { Full Sample } & 0.1003 & 0.6167 \\ \text { Quartile 1 } & 0.1527 & 0.5051 \\ \text { Quartile 2 } & 0.0916 & 0.5454 \\ \text { Quartile 3 } & 0.1190 & 0.7201 \\ \text { Quartile 4 } & 0.0388 & 0.7002\end{array}$

Advert.-to-Assets

Work Cap.-to-Assets

Full Sample

Quartile 1

Quartile 2

Quartile 3

Quartile 4

Mean Std. Dev

$\begin{array}{ccc}\text { R\&D-to-Assets } & & \\ \text { Full Sample } & 0.2494 & 0.2664 \\ \text { Quartile 1 } & 0.0393 & 0.0212 \\ \text { Quartile 2 } & 0.1104 & 0.0303 \\ \text { Quartile 3 } & 0.2571 & 0.0533 \\ \text { Quartile 4 } & 0.5910 & 0.3133\end{array}$

Cap. Exp.-to-Assets

Full Sample $\quad 0.0682 \quad 0.0632$

$\begin{array}{lll}\text { Quartile 1 } & 0.0568 & 0.0599\end{array}$

Quartile $20.0938 \quad 0.0627$

$\begin{array}{lll}\text { Quartile } 3 & 0.0521 & 0.0605\end{array}$

$\begin{array}{lll}\text { Quartile } 4 & 0.0694 & 0.0643\end{array}$

Full Sample $\quad 0.0451 \quad 0.0777$

$\begin{array}{lll}\text { Quartile 1 } & 0.0534 & 0.0954\end{array}$

$\begin{array}{lll}\text { Quartile 2 } & 0.0938 & 0.0627\end{array}$

Quartile $3 \quad 0.0115 \quad 0.0143$

$\begin{array}{lll}\text { Quartile } 4 & 0.0132 & 0.0107\end{array}$

Pre-event Period

Return Volatility

$\begin{array}{lll}\text { Full Sample } & 0.0420 & 0.0167 \\ \text { Quartile 1 } & 0.0347 & 0.0138 \\ \text { Quartile 2 } & 0.0325 & 0.0186 \\ \text { Quartile 3 } & 0.0500 & 0.0121 \\ \text { Quartile 4 } & 0.0512 & 0.0127\end{array}$

Debt-to-Assets

$\begin{array}{lll}\text { Full Sample } & 0.1583 & 0.1833 \\ \text { Quartile 1 } & 0.2180 & 0.1527 \\ \text { Quartile 2 } & 0.1744 & 0.1426 \\ \text { Quartile 3 } & 0.0900 & 0.1476 \\ \text { Quartile 4 } & 0.1120 & 0.1280\end{array}$




\begin{tabular}{ccc} 
Return Volatility Change & & \\
Full Sample & -0.0016 & 0.0124 \\
Quartile 1 & -0.0001 & 0.0093 \\
Quartile 2 & -0.0005 & 0.0120 \\
Quartile 3 & -0.0056 & 0.0108 \\
Quartile 4 & -0.0014 & 0.0164 \\
\hline
\end{tabular}


Table II. Value-Weighted Cumulative Abnormal Returns for a Portfolio of 111 Pharmaceutical and Biotechnology Companies

Cumulative abnormal returns (CARs) for each of the following events are calculated using the market model with the CRSP value-weighted index return as the market return. CARs cover 11 trading days; five trading days before the event, the event day, and five trading days after the event. Each of these events was considered to be a potentially important political event that could have made pharmaceutical price controls more likely. HSA-related return, used in the study tests, includes only the CARs for the last four events. These events are most closely linked to the HSA and occurred after Clinton was elected president. The t-statistic is based on a time series standard deviation of the portfolio mean abnormal returns during the market model estimation, as suggested in Brown and Warner (1980) to avoid bias from cross-sectional correlation of returns.

\begin{tabular}{lll}
\hline Date of Event & Description of HSA-Related Event & Cumulative t-statistic
\end{tabular} Abnormal Return (\%)

January 19, 1992 Clinton issues health care reform proposals before New Hampshire primary. $\quad-8.41 \quad-4.49^{*}$

February 18, 1992 Clinton unexpectedly finishes second in the New Hampshire primary. $\quad-3.79 \quad-2.02 *$

March 10, 1992 Clinton does well in the Super Tuesday primaries.

$-3.04-1.62 * *$

April 7, 1992

Clinton wins New York primary and becomes the favorite to win the Democratic Nomination.

1.01

0.54

June 4, 1992

Republicans in the House of Representatives offer their health care reform proposal.

September 24, 1992 Clinton speaks at Merck on health care reform. $-6.31-3.37 *$

November 3, 1992 Clinton wins presidential election.

$-0.85 \quad-0.45$

January 25, 1993

Clinton names Hillary Clinton to head his Health Care Task Force.

February 12, 1993 Clinton says drug prices are too high.

September 11, 1993 New York Times describes probable regulations based upon a leaked copy of the plan.

September 22, 1993 Clinton officially announces his health care reform plan.

Total for the 11 events. \begin{tabular}{ll}
-3.27 & $-1.74 * *$ \\
\hline-45.50 & $-5.19 *$
\end{tabular} Total for the four events in 1993. $-19.01 \quad-8.14 *$

\footnotetext{
* (**) Cumulative abnormal return is significant at the $1 \%(10 \%)$ level in a one-tailed test.
} 

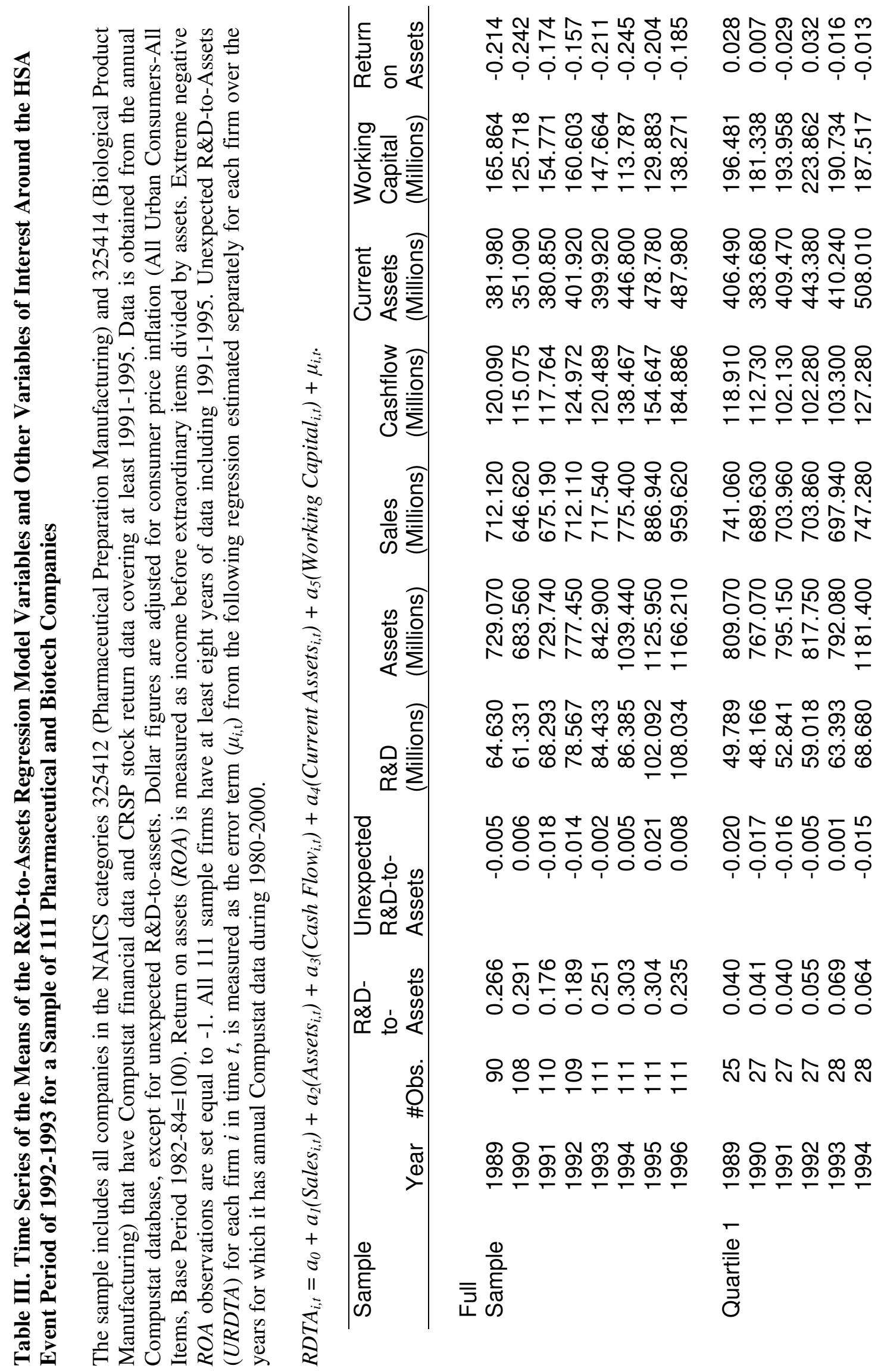


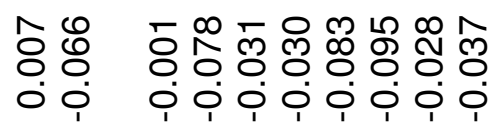

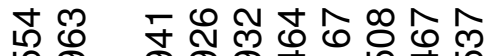

Tho ofos

舟㐫

․

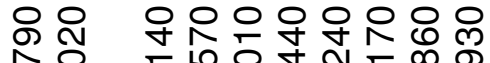

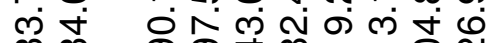

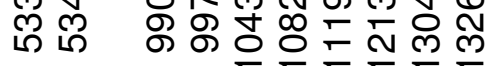

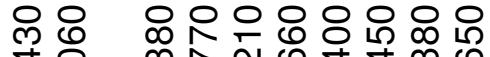

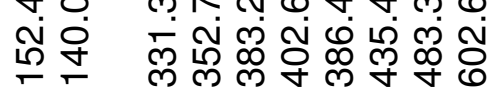

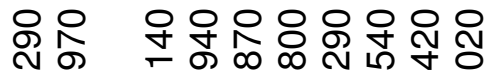

लि.

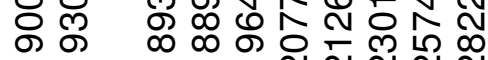

응우 웅이응응ㅇㅇㅇ

ติ

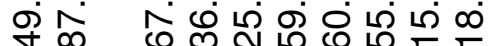

뜬

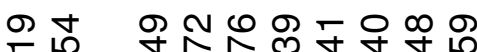

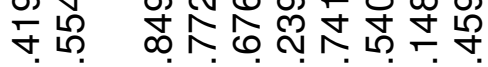

ம

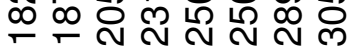

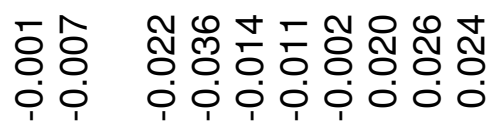

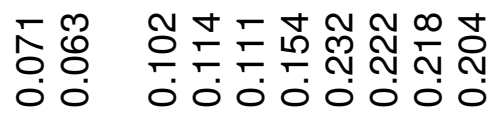

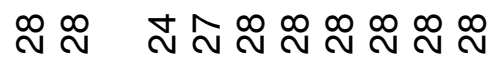

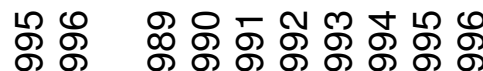

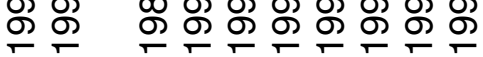

Q
$\frac{0}{\frac{\pi}{2}}$
$\frac{\pi}{2}$

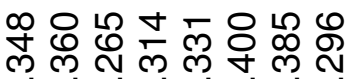

○' ơ

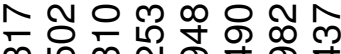

का मू ले के क्षे

+̛

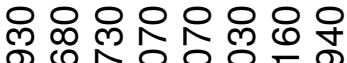

ம்

잉웡ㅇㅇ옹ㅇㅇ워오

ヘ่

잉ㅇㅇㅇㅇㅇㅇㅇ우음 子 ल N ナं

응ㅇㅇ오으웅ㅇㅇ 㠃 N

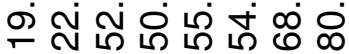

스 $\infty$ б̄ं ナம

N $\cong \infty \sim 0 \%$

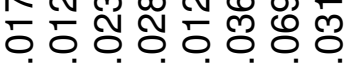

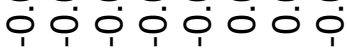

수욤요

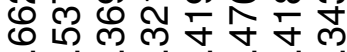
i

ᄋิธ $\infty$ 으잉

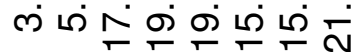

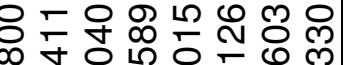
ช

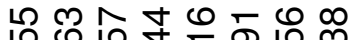
م으유

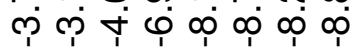

N $\infty m \infty$

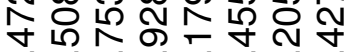
- लें⿰丿⺄帀

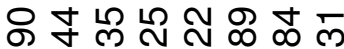
$0 N-\infty$ in $\infty$

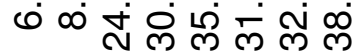

సั

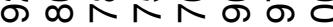
ल लंभं

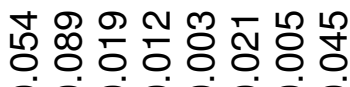
○.

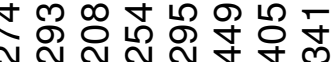
○००0000

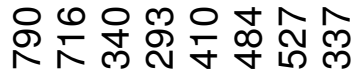
00000000

ำลลลลลล ลิ

$\stackrel{\infty}{\sim} \widehat{N} \stackrel{\infty}{\sim} \stackrel{\infty}{\sim} \stackrel{\infty}{\sim} \stackrel{\infty}{\sim} \stackrel{\infty}{N}$

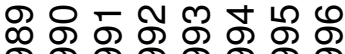
이윰으음

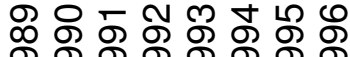
으으으으음ㅇ 


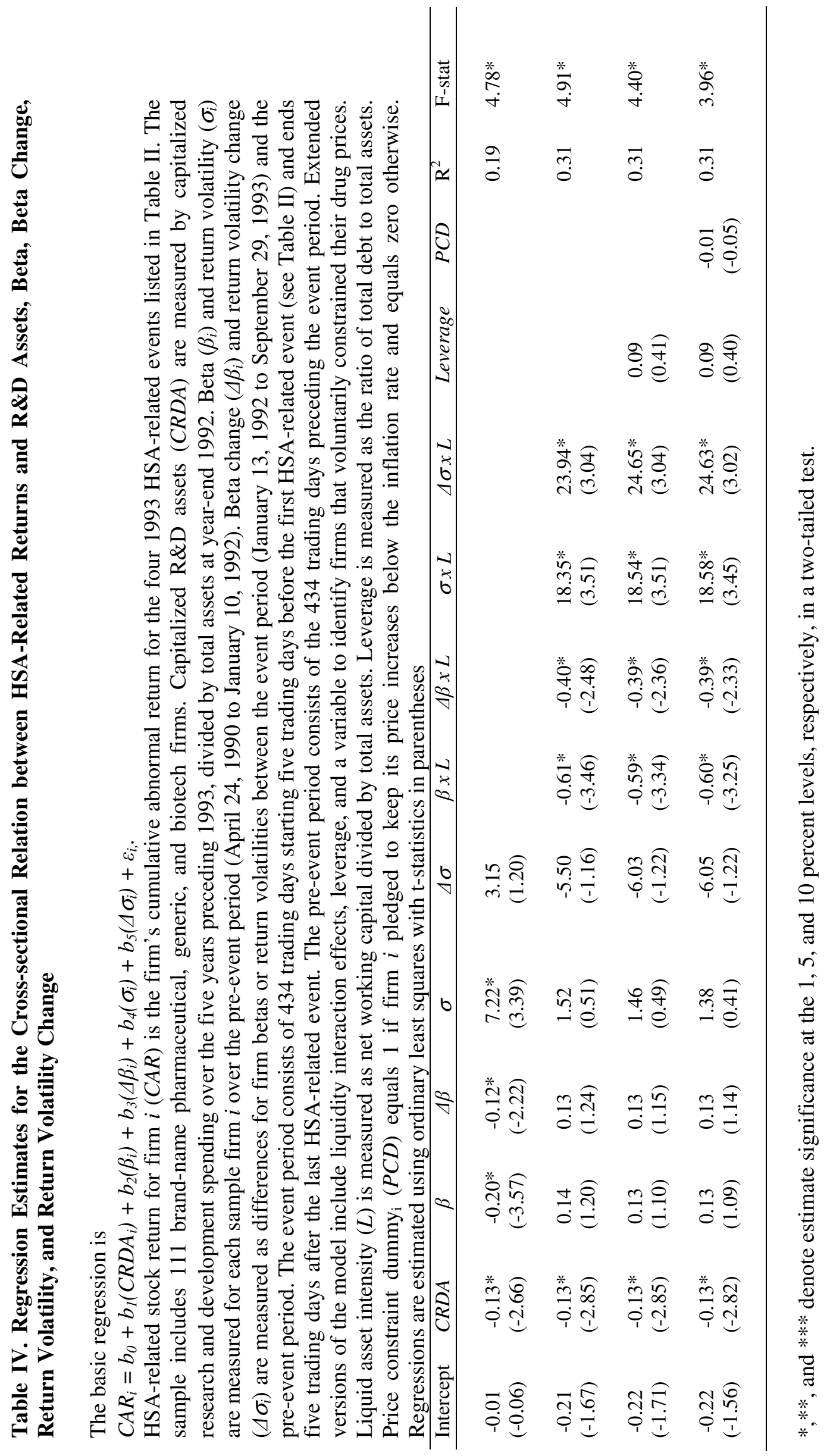




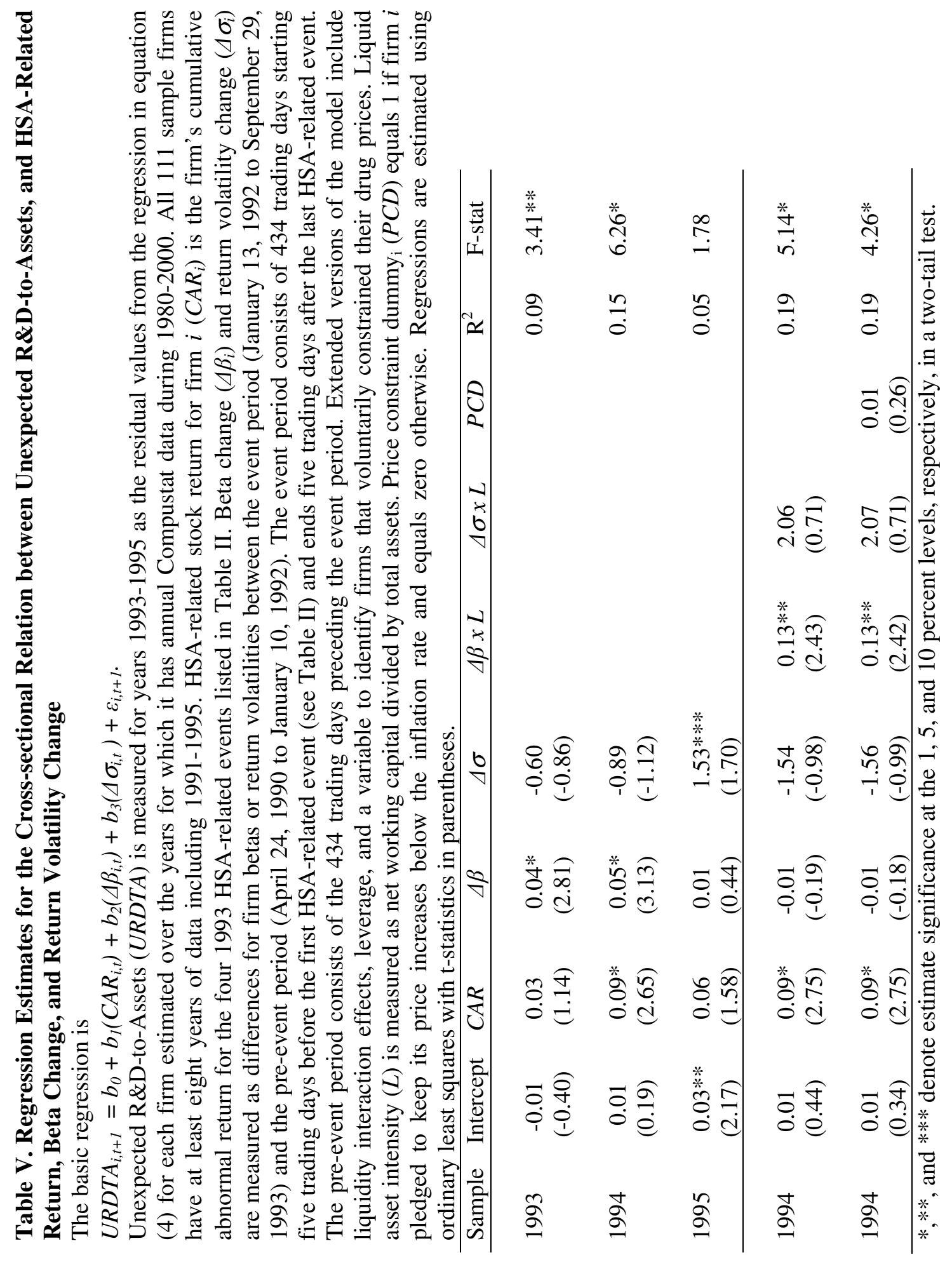




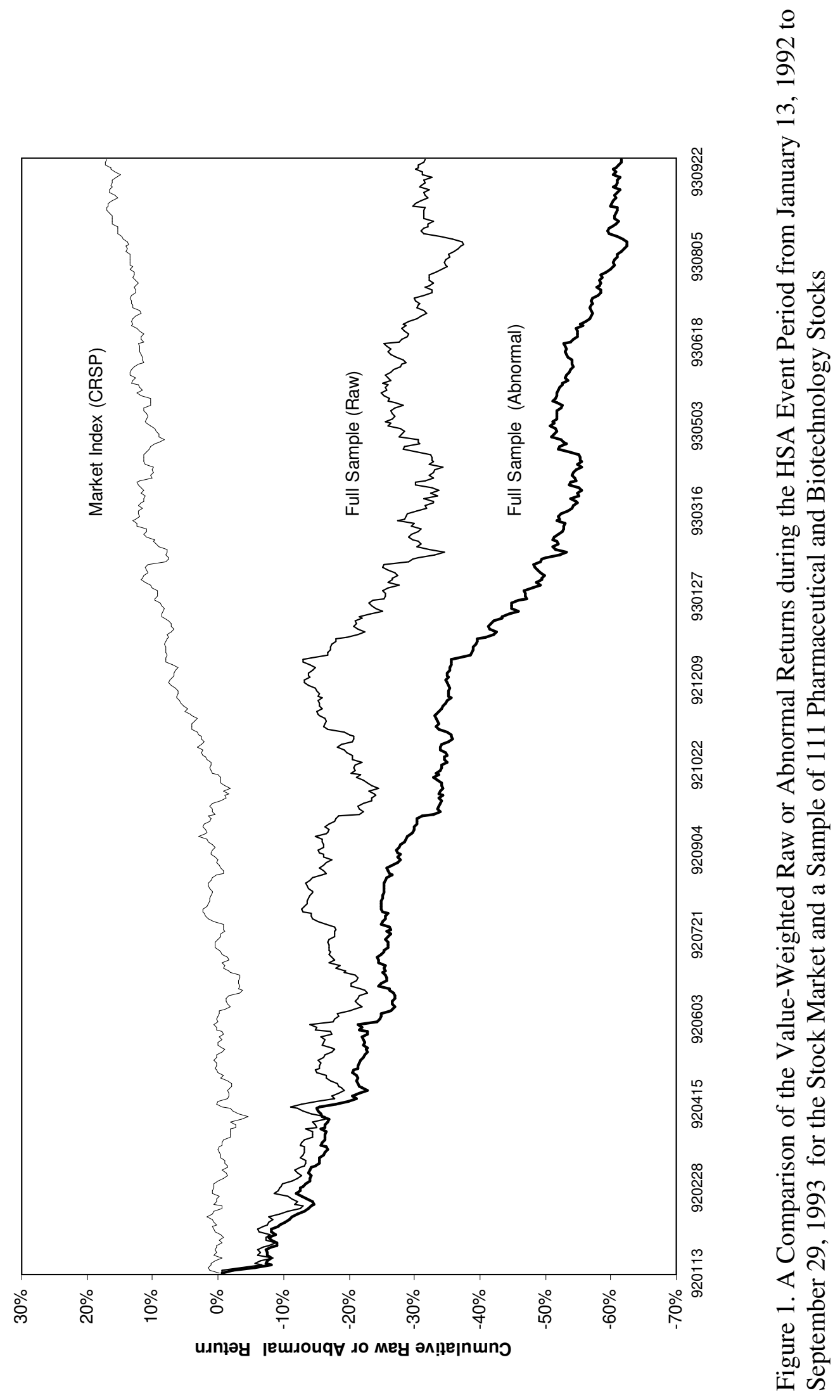




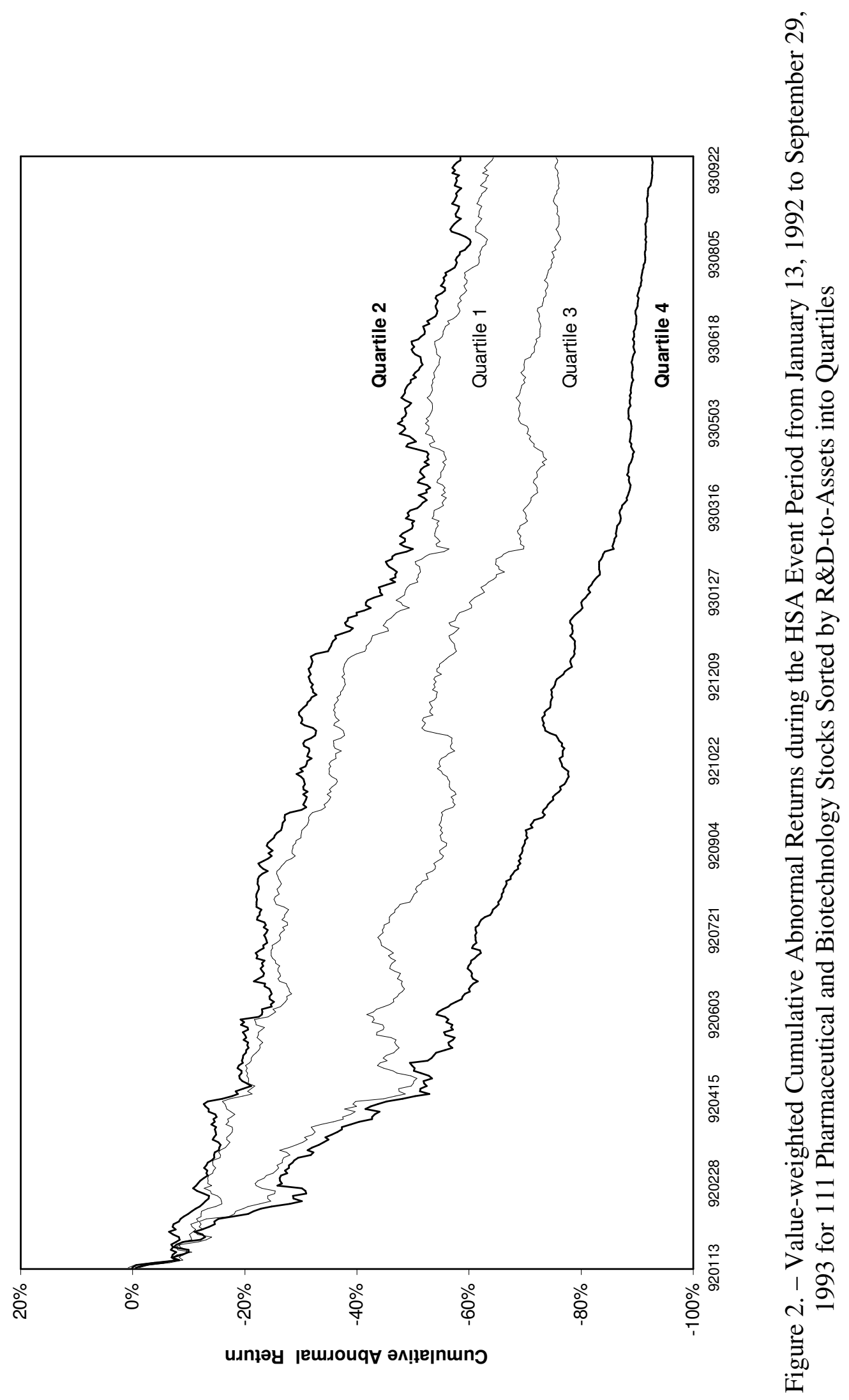




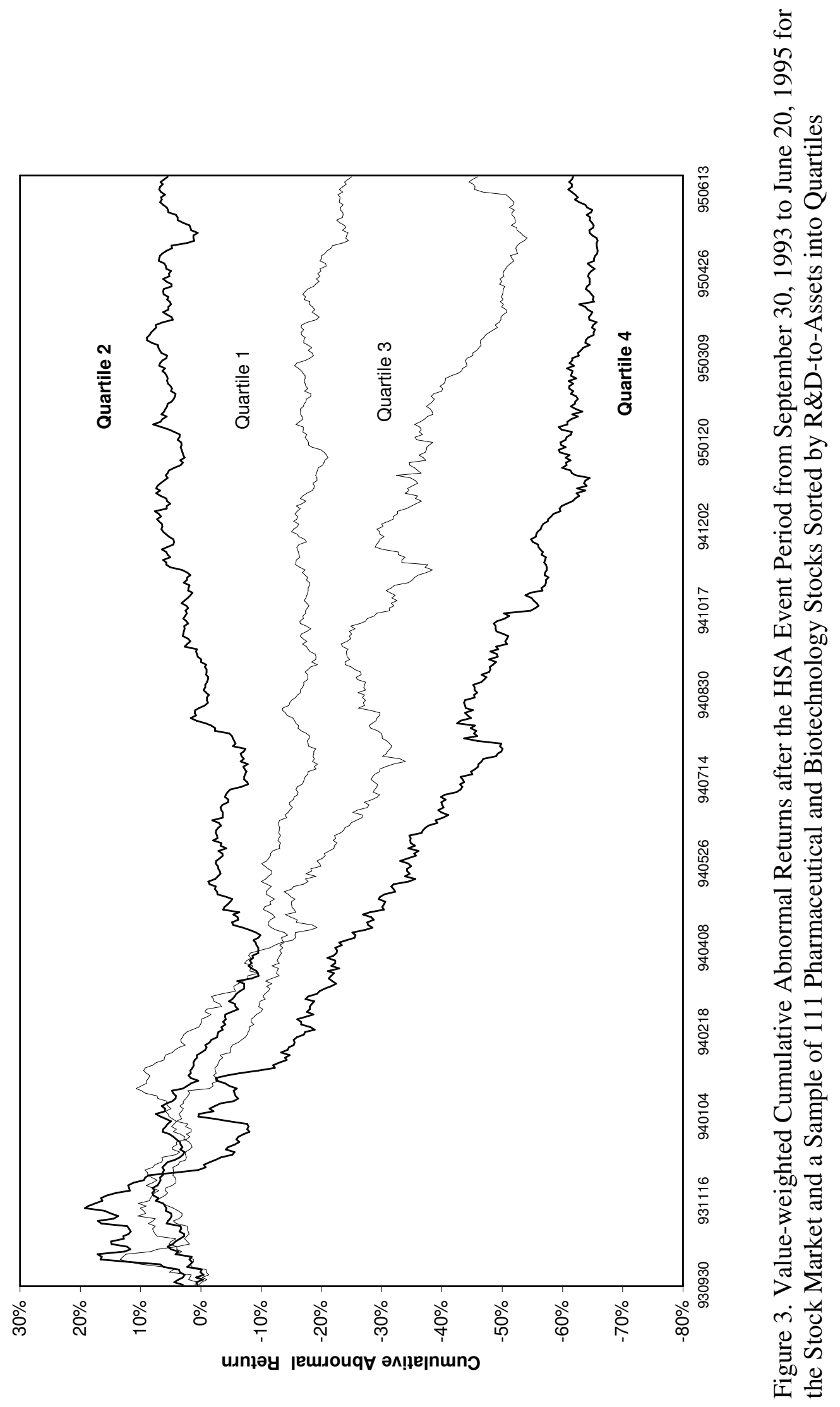

